\title{
Neighbourhood Determinants of Early Sexual Debut and Multiple Sexual Partnerships: A cross-sectional Analysis of Adolescents in Rwanda, Ghana and South Africa.
}

Nebechukwu Henry Ugwu ( $\square$ henryhills02@yahoo.com )

University of the Witwatersrand

Clifford Obby Odimegwu

University of the Witwatersrand

\section{Research Article}

Keywords: poverty, education, media, youth, HIV/AIDS, Africa

Posted Date: October 18th, 2021

DOI: https://doi.org/10.21203/rs.3.rs-952816/v1

License: (1) This work is licensed under a Creative Commons Attribution 4.0 International License. Read Full License 


\section{Abstract}

Background: The relationship between neighbourhood characteristics and youth involvement in risky sexual behaviour such as early sexual debut and multiple sexual partnerships is well established in the literature. However, there are very few empirical studies using Demographic and Health Surveys to unpack the nature of this relationship in Africa. This study aims to identify the neighbourhood characteristics influencing young people's engagement in risky sexual behaviour in sub-Saharan Africa.

Methods: Univariate, bivariate, and multivariate analyses on young people aged 15 to 24 years were conducted using the most recent Demographic and Health Survey Data (DHS 2014-2016) from Ghana, Rwanda, and South Africa to investigate the relationship between neighbourhood characteristics and youth risky sexual behaviour.

Results: Individual and, in particular, neighbourhood characteristics (community poverty, community occupation, community media access, and community education) were found to be substantially linked with youth risky sexual behaviour.

Conclusion: To lower the incidence of risky sexual behaviour in the community, programs aimed at appropriate policy options must be intensified. Adopting the implications of these findings is critical for a developmental approach aimed at reaching Africa's long-term development goal of eliminating STls among young people.

\section{Background}

Transitioning from childhood to early adulthood has been identified as one of the most crucial life transition stages, according to studies conducted in the last decades. Young individuals go through a lot of behavioural and attitudinal changes throughout this period $[1,2]$. These stages are marked by a mix of tension and excitement, particularly during the first sexual encounters [3]. Sexuality is one of the earliest changes in the transition, and it has long-term consequences for the health and well-being of this young population $[4,5]$. As a result, if sexuality is not effectively managed, these youth's potentials in later years are harmed because of a lack of better opportunities for independent decision-making.

In sub-Saharan Africa, issues about fulfilling the needs of youth due to their involvement in risky sexual behaviour remain at the top of the national agenda of sexual and reproductive health programs [6, 7]. Some of these programs include HIV testing and counselling (HTC), Condom use initiatives, Behavioural change and communication (BCC) and Voluntary male circumcision. In recent years, these preventive initiatives aimed at reducing the risks of sexual behaviour that imperil the lives of these young populations $[6,8]$. There has been evidence of a decrease in the age at menarche in young females $[9,10]$. The age at which females were sexually mature, as well as the age at which male adolescents became sexually mature, has changed [11]. Early maturation may be accompanied by a decrease in the age at which young individuals begin their first sexual encounters [12]. It was reported that people who started having sex at a young age are more likely at risk of poor sexual and reproductive health outcomes, such as sexually transmitted infections (STIs), and HIV/AIDS, abortion, intimate partner violence and undesired pregnancies $[13,14]$.

Early sexual debut has also been demonstrated to increase the risk of inconsistency in condom use, which can lead to several sexual partners among young people $[15,16]$. This behaviour can harm a young person's reproductive health and overall quality of life. While the implications of this shift can be seen in sub-Saharan Africa and other emerging countries, they are especially concerning in countries where HIV/AIDS is prevalent $[17,18]$. For example, in a qualitative study conducted in China, it was documented that $65 \%$ of the nearly 14,000 HIV-positive individuals diagnosed in ten months, were young people [19]. Another research of adolescents in the United States found a rise in youth engagement in risky sexual behaviour, particularly among Black Americans; [20] cited a desire for financial benefits as one of the reasons, particularly among older adolescents. More so, in Rwanda, a population-based HIV impact assessment (2018-2019) report indicate that $2 \%$ of HIV prevalence is to the youth aged 15 to 24 years old [21]. The increase in their assessment report was due to their early sexual debut and multiple sexual partners [22]. Despite increased studies over the last two decades on the factors responsible for infections among Rwandan youth, there has been no good improvement in young people's SRH [21]. In addition, early sexual debut and multiple sexual partnerships among the youth is also a major concern in Ghana [23]. According to a study conducted in Ghana, $65.4 \%$ of the youth did not use a condom in their last sex, $51.8 \%$ of the sexually active youth started sex before age 14 (Dine et al., 2021). Furthermore, in South Africa, $39 \%$ of sexually active youth made their sexual debut before the age of 16 , implying that young people are still engaging in risky sexual behaviour.

The high prevalence rate of STIs, as well as HIV/AIDS, particularly among these large youth populations has become a source of worry within the region. For instance, the World Health Organization reported that within the WHO African region, more than $60 \%$ of the general population is infected with the infection in 2021 [24], with young females between aged 15 and 24 years old having the large share. Studies

Page $2 / 25$ 
have documented an association between neighbourhood characteristics and risky sexual behaviour [25, 26]. For example, in a crosssectional study in SSA examining the influence of poverty and sexual behaviour, the result revealed that not being poor delays sexual debut in females and poor female adolescents are vulnerable to infectious diseases [27]. Similarly, in another study in SSA using a crosssectional design document age, urban residence, education attainment and media exposure at the individual level resulted in the likelihood of risky sexual behaviour [28]. However, very few studies recommended that further research exploring neighbourhood level characteristics need to be done in SSA [29,30]. Durkelman and colleagues stressed the influence of lack of food in the community on the likelihood of engaging in multiple sexual partnerships among young females. Another study by Liu and colleagues found a link between neighbourhood characteristics and the risk of youth engaging in multiple sexual partnerships. The study emphasized how cultural norms and values in neighbourhoods have a detrimental impact on risky sexual behaviour [31]. As a result, it is critical to lessen the burden of sickness that plagues individuals and families in SSA, particularly among young people, by looking beyond individual variables.

The social disorganization frameworks were chosen for this study because they demonstrate that high-risk sexual activity is a complex phenomenon that involves the interaction of individual, community, and societal components [32]. Furthermore, individual and community self-regulatory capacities are eroded by age, education, employment status, neighbourhood poverty, volatility, and family upheaval. The theory of social disorganisation is used to explain how individual and community factors such as poverty, family disruptions, residential instability, and race/ethnic disparities influence the reproductive health of people living in certain neighbourhoods, including youth themselves, directly or indirectly [33]. Therefore, this paper seeks to examine the relationships between neighbourhood factors and sexual behaviour among youth. It hypothesizes that neighbourhood factors such as community poverty, community media access, community education and community occupation are associated with adolescents' sexual behaviour in SSA.

\section{Methods}

This study used data from the Demographic and Health Survey (DHS) from Ghana, Rwanda and South Africa, which was a survey conducted nationally within five years. For this study, a total of 14,751 youth aged 15 to 24 years comprising 9,271 females and 5,480 males were used.

\section{Inclusion criteria for the countries selected.}

The availability of data on an adolescent's sexual risk, as well as consistency in sexual-risk behaviour in connection to neighbourhood variables, were the criteria for including the DHS data for the selected countries in this study

\section{Outcome Variables}

The study made use of two outcome/dependent sexual risk behaviour variables of multiple sexual behaviour and age at first sex. For multiple sexual partnerships, respondents were asked if they have had more than one sexual partner in the 12 months preceding the survey and risky sex was defined as any sexual intercourse with a non-marital or non-cohabiting partner in the last 12 months before the survey. Their responses were then grouped into 1 = yes if they have more than one sexual partner, and $0=$ No if they responded otherwise. For the age at first sexual intercourse, respondents were asked the age they had their first sex. Their responses were then grouped into < 18 years: $<24$ years and No sex between 15 and 24 years.

\section{Measurements of variables}

\section{Individual-level variables}

The following individual-level explanatory variables were included as control variables: age of the respondent at the time of the interview (15-19 or 20-24): education attainment (Primary/less education, secondary or higher): employment status (not working or working): household size (1-4, 5-6 or 7+) members.

\section{Neighbourhood-level variables}

The neighbourhood-level variables included in the study were (1) neighbourhood poverty: percentage of households in the poorest quintile of the wealth index [34]. (2) Place of residence was defined as either rural or urban, as administratively defined by each of the countries surveyed. (3) Community education was defined as the level of educational attainment in the household, categorized as (i) low (ii) high. (4) Community occupation categorized as (i) Not working (ii) professional (iii) Sales/unspecified (iv) agriculture (v) manual. (5) Community media access was defined as those who have access to radio in the community which was categorized as (i) low (ii) high. To make analyses and interpretations simpler and more meaningful, some variables were regrouped from their original categories in the dataset.

\section{Data Analysis}


Data were weighted using the weight weighting factors of the demographic health surveys. The relationship between each of the outcome variables of risky sexual behaviour and independent variables were assessed using descriptive, bivariate and multivariate analysis.

Multilevel logistic regression analysis was employed to adjust to interrelationships between covariance. Three models were fitted for each of the outcome variables: empty models (model 1) individual (model 2) and neighbourhoods (model 3). Multi-collinearity was assessed among the variables. And there was no multi-collinearity. STATA 14 Software was used for the analysis.

\section{Ethical Consideration.}

The study utilized secondary datasets from Ghana, Rwanda and South Africa with all identifier information removed. The survey was approved by the Ethics Committee of the Micro at Calverton in the USA and by the National Ethics Committee of each of the countries surveyed. All study participants gave informed consent before participation and all information was collected confidentially. The datasets were downloaded from the DHS website and are free to be used by researchers for further analysis.

\section{Results}

\section{Background characteristics}

The descriptive analysis of the study population by the background characteristics were presented in Table 1 below. In the three countries surveyed, the proportion of respondents for both the male and females aged 15 to 19 years ranges from 65.7\% (Ghana) to 64\% (Rwanda). Only South Africa had less than $60 \%$ of those between age 15 and 19 years for both males and females. Rwanda had $39.3 \%$ of the male adolescent, $38 \%$ male adolescents were from Ghana. South Africa recorded the highest proportion of the males and females without any employment at the time of the survey at $91.4 \%$ and $83.7 \%$ respectively, while the least is Rwanda at $43 \%$ females and $34.6 \%$ for the males. With regards to education attainments, respondents who had secondary education attainment were the majority, $87.9 \%$ for females and 82.4\% males (South Africa), 73.5\% females and 72.4\% males (Ghana) and $44.4 \%$ females and $38.6 \%$ males (Rwanda). In terms of household size, South Africa recorded the highest proportion of those from a household made up of 1 to 4 members among the males at 45.7\%, 37.5\% (Ghana) and 34.7\% (Rwanda).

Additionally, Rwanda recorded the highest proportion of male and female respondents who are living in a neighbourhood with a low poverty level at $73.8 \%$ males and $69.6 \%$ females. Ghana and South Africa had more than $40 \%$ of their male and female youth living in a neighbourhood with high poverty levels. In terms of community media accessibility, those with no access ranges from $34.6 \%$ females (South Africa), and $18.7 \%$ females (Ghana) to $10.5 \%$ females (Rwanda). With regards to the community occupation, more than $50 \%$ of males and females did not have any job from all the countries surveyed. Apart from South Africa which recorded the highest proportion of those living in a community with low education for the males and females at more than $70 \%$, the rest of the countries had a little above $50 \%$ of those living in a community with low education. More so, apart from South Africa which recorded the highest proportion of young people who resided in the urban areas, the rest of the surveyed countries had the highest proportion residing in the rural areas, ranging from 73.5\% males and 71.2\% females (Rwanda), and 54.3\% males and 49.3\% females (Ghana) to 53.1\% males (South Africa). In all, there was substantial representation across gender in all the countries surveyed. 
Table 1

Background characteristics

\begin{tabular}{|c|c|c|c|c|c|c|c|c|c|c|c|c|}
\hline \multirow[b]{3}{*}{ Characteristic } & \multicolumn{4}{|c|}{ Ghana } & \multicolumn{4}{|c|}{ Rwanda } & \multicolumn{4}{|c|}{ South Africa } \\
\hline & \multicolumn{2}{|c|}{ Female } & \multicolumn{2}{|l|}{ Male } & \multicolumn{2}{|c|}{ Female } & \multicolumn{2}{|l|}{ Male } & \multicolumn{2}{|l|}{ Female } & \multicolumn{2}{|l|}{ Male } \\
\hline & Freq. & $\%$ & Freq. & $\%$ & Freq. & $\%$ & Freq. & $\%$ & Freq. & $\%$ & Freq. & $\%$ \\
\hline \multicolumn{13}{|l|}{ Respondent age } \\
\hline $15-19$ & 1,623 & 65.7 & 886 & 62 & 2,676 & 64.0 & 1,278 & 60.7 & 1,461 & 55.7 & 704 & 55.5 \\
\hline $20-24$ & 849 & 34.3 & 542 & 38 & 1,502 & 35.9 & 827 & 39.3 & 1,160 & 44.3 & 564 & 44.5 \\
\hline \multicolumn{13}{|l|}{ Employment status } \\
\hline No & 1,544 & 62.6 & 642 & 45 & 1,791 & 43.0 & 726 & 34.6 & 2,396 & 91.4 & 1,061 & 83.7 \\
\hline Yes & 924 & 37.4 & 785 & 55 & 2,371 & 56.9 & 1,370 & 65.4 & 225 & 8.6 & 207 & 16.3 \\
\hline \multicolumn{13}{|c|}{ Respondent education attainment } \\
\hline $\begin{array}{l}\text { Primary and less } \\
\text { education }\end{array}$ & 555 & 22.4 & 337 & 23.6 & 2,249 & 53.8 & 1,238 & 58.8 & 157 & 5.9 & 172 & 13.6 \\
\hline Secondary & 1,817 & 73.5 & 1034 & 72.4 & 1,855 & 44.4 & 813 & 38.6 & 2,306 & 87.9 & 1,045 & 82.4 \\
\hline Higher & 100 & 4.0 & 57 & 4 & 74 & 1.8 & 54 & 2.6 & 158 & 6.0 & 51 & 4.0 \\
\hline \multicolumn{13}{|l|}{ Household size } \\
\hline $1-4$ & 906 & 36.6 & 536 & 37.5 & 1,189 & 28.5 & 730 & 34.7 & 977 & 37.3 & 579 & 45.7 \\
\hline $5-6$ & 775 & 31.3 & 416 & 29.1 & 1,388 & 33.2 & 662 & 31.4 & 750 & 28.6 & 310 & 24.4 \\
\hline $7+$ & 791 & 32 & 476 & 33.3 & 1,601 & 38.3 & 713 & 33.9 & 894 & 34.1 & 379 & 29.9 \\
\hline \multicolumn{13}{|c|}{ Neighbourhood poverty } \\
\hline Low (wealth low) & 1,400 & 56.6 & 715 & 51 & 2,910 & 69.6 & 1,554 & 73.8 & 1,441 & 54.9 & 665 & 52.4 \\
\hline High (wealth high) & 1072 & 43.4 & 713 & 49.9 & 1,268 & 30.3 & 551 & 26.2 & 1,180 & 45.0 & 603 & 47.6 \\
\hline \multicolumn{13}{|c|}{ Community media access } \\
\hline No access & 462 & 18.7 & 125 & 8.7 & 437 & 10.5 & 200 & 9.51 & 908 & 34.6 & 293 & 23.1 \\
\hline Not regular & 812 & 33 & 318 & 22.3 & 836 & 20.0 & 229 & 10.9 & 482 & 18.4 & 337 & 26.6 \\
\hline Regularly & 1198 & 48.5 & 985 & 69 & 2,900 & 69.5 & 1,674 & 79.6 & 1,231 & 46.9 & 638 & 50.3 \\
\hline \multicolumn{13}{|c|}{ Community occupation } \\
\hline Not working & 1469 & 59.4 & 561 & 39.3 & 1,436 & 34.4 & 693 & 33 & 2,336 & 89.1 & 988 & 77.9 \\
\hline Professionals & 115 & 4.6 & 71 & 4.9 & 59 & 1.4 & 35 & 1.7 & 113 & 4.3 & 30 & 2.4 \\
\hline Sales/unspecified & 434 & 17.6 & 97 & 6.8 & 252 & 6.0 & 120 & 5.7 & 15 & 0.6 & 13 & 1.0 \\
\hline Agriculture & 270 & 10.9 & 461 & 32.3 & 2,267 & 54.4 & 922 & 43.9 & 33 & 1.3 & 53 & 4.2 \\
\hline Manual & 183 & 7.4 & 236 & 16.5 & 155 & 3.7 & 330 & 15.7 & 124 & 4.7 & 184 & 14.5 \\
\hline \multicolumn{13}{|c|}{ Community education } \\
\hline Low & 1718 & 69.5 & 991 & 69.4 & 2,249 & 53.8 & 1,238 & 58.8 & 1,910 & 72.9 & 1,001 & 78.9 \\
\hline High & 754 & 30.5 & 437 & 30.6 & 1,929 & 46.2 & 867 & 41.2 & 711 & 27.1 & 267 & 21.0 \\
\hline \multicolumn{13}{|l|}{ Place of residence } \\
\hline Urban & 1254 & 50.7 & 653 & 45.7 & 1,201 & 28.7 & 558 & 26.5 & 1,393 & 53.1 & 594 & 46.8 \\
\hline
\end{tabular}




\begin{tabular}{|c|c|c|c|c|c|c|c|c|c|c|c|c|}
\hline \multirow[b]{2}{*}{ Rural } & \multicolumn{3}{|c|}{ Ghana } & \multicolumn{5}{|c|}{ Rwanda } & \multicolumn{4}{|c|}{ South Africa } \\
\hline & 1218 & 49.3 & 775 & 54.3 & 2,977 & 71.2 & 1,547 & 73.5 & 1,228 & 46.8 & 674 & 53.1 \\
\hline
\end{tabular}

\section{The prevalence of adolescent risky sexual behaviour}

In the three countries surveyed as shown in figure 1 below, the rate of adolescents who reported to have engaged in multiple sexual partners ranges from $12 \%$ females and $13 \%$ males (Rwanda), $38 \%$ females and $30 \%$ males (Ghana), to $56 \%$ female $62 \%$ males (South Africa) as shown in Table 2 below. Those that started their first sexual encounter between ages 18 and 24 years old were highest among South Africa male adolescents at $22 \%$, while the least is Rwandan female adolescents at $11 \%$. In all the countries surveyed, those who have not had sex before their 24th birthday ranges from 75\% Females (Rwanda), 49\% females (Ghana), and 37\% females (South Africa). Association with adolescent risky sexual behaviour and employment status was evident in all the three countries surveyed. The proportion of those without any employment to have been exposed to risky sexual behaviour ranges from $63 \%$ females and $45 \%$ males (Ghana), $43 \%$ females and 35\% males (Rwanda), to 91\% females and 84\% males (South Africa).

In all the three countries surveyed as shown in figure 2, it was found that more than $50 \%$ of adolescent males and females with secondary education attainments had engaged in risky sexual behaviour compared to the $22 \%$ and $44 \%$ with a primary or fewer education attainments. Association of adolescent risky sexual behaviour with the neighbourhood poverty level ranges from $70 \%$ females and $74 \%$ males (Rwanda) to more than $50 \%$ for both genders in South Africa and Ghana. A similar pattern was observed for community media access as more than $60 \%$ of adolescent males and females with regular access to media in Rwanda have engaged in risky sexual behaviour. While $50 \%$ males and $47 \%$ females (South Africa) to $49 \%$ males and $69 \%$ females (Ghana) with regular access to media have engaged in risky sexual behaviour. For those in a high education community, the highest proportion was Rwanda with $46 \%$ females and $41 \%$ males. In all the countries surveyed, there was evidence of community characteristics influencing adolescents to have engaged in risky sexual behaviours.

\section{Adolescent risky sexual behaviour predictors}

The association between background characteristics and multiple sexual partnerships is presented in Table 2 . The odds of having multiple sexual partners increased as age increased in all the three countries surveyed. After adjusting for all the other variables, female respondents in the 20 to 24 age category were significantly likely to have multiple sexual partners compared to those aged 15 to 19 years of Ghana (AOR = 3.72, 95\% Cl: 2.93), Rwanda (AOR = 2.77, 95\% Cl: 2.26-3.40) and South Africa (AOR = 5.19, 95\% Cl:4.25-6.33). Those with higher education attainments in Ghana and Rwanda were associated significantly at lower odds of engaging in multiple sexual partnerships at $(\mathrm{AOR}=0.74,95 \% \mathrm{Cl}$ : $0.44-1.24)$ and $(\mathrm{AOR}=0.14,95 \% \mathrm{Cl}: 0.04-0.46)$. Meanwhile, female adolescents from a household of 5 to 6 members in Ghana and Rwanda were $82 \%$ and $74 \%$ unlikely to have multiple sexual partners compared to those in South Africa with a $3 \%$ likelihood to have multiple sexual partners. 
Table 2

Odds Ratios of Multiple sexual partners by selected Background Characteristic (Females)

\begin{tabular}{|c|c|c|c|c|c|c|}
\hline & \multicolumn{2}{|l|}{ Ghana } & \multicolumn{2}{|l|}{ Rwanda } & \multicolumn{2}{|l|}{ South Africa } \\
\hline & \multicolumn{2}{|l|}{ Female } & \multicolumn{2}{|l|}{ Female } & \multicolumn{2}{|l|}{ Female } \\
\hline & OR & aOR & OR & aOR & OR & aOR \\
\hline \multicolumn{7}{|l|}{ Respondent age } \\
\hline 15-19 RC & 1 & 1 & 1 & 1 & 1 & 1 \\
\hline $20-24$ & $\begin{array}{l}3.93^{\star * \star}(3.29- \\
4.68)\end{array}$ & $\begin{array}{l}3.7 * * \star(2.93- \\
4.44)\end{array}$ & $\begin{array}{l}2.89 * \star \star \\
3.50)\end{array}$ & $\begin{array}{l}2.77 * \star \star 2.26- \\
3.40)\end{array}$ & $\begin{array}{l}6.31 * \star \star \\
7.54)\end{array}$ & $\begin{array}{l}5.19 * * *(4.25- \\
6.33)\end{array}$ \\
\hline \multicolumn{7}{|l|}{ Employment status } \\
\hline NO RC & 1 & 1 & 1 & 1 & 1 & 1 \\
\hline Yes & $\begin{array}{l}1.96 * * *(1.65- \\
2.32)\end{array}$ & $\begin{array}{l}0.67(0.40- \\
1.09)\end{array}$ & $\begin{array}{l}1.65^{\star * *}(1.35- \\
2.02)\end{array}$ & $\begin{array}{l}0.98(0.70- \\
1.37)\end{array}$ & $\begin{array}{l}3.06 * \star \star \\
4.25)\end{array}$ & $\begin{array}{l}0.89(0.41- \\
1.93)\end{array}$ \\
\hline \multicolumn{7}{|c|}{ Respondent education attainment } \\
\hline $\begin{array}{l}\text { Primary and less } \\
\text { education RC }\end{array}$ & 1 & 1 & 1 & 1 & 1 & 1 \\
\hline Secondary & $\begin{array}{l}1.32 \text { (1.07- } \\
1.60)\end{array}$ & $\begin{array}{l}1.17(0.92- \\
1.47)\end{array}$ & $\begin{array}{l}0.88(0.72- \\
1.06)\end{array}$ & $\begin{array}{l}0.83(0.67- \\
1.04)\end{array}$ & $\begin{array}{l}1.79 * \star \star \\
2.49)\end{array}$ & $\begin{array}{l}1.57 *(1.09- \\
2.26)\end{array}$ \\
\hline Higher & $\begin{array}{l}1.79(1.16- \\
2.75)\end{array}$ & $\begin{array}{l}0.74(0.44- \\
1.24)\end{array}$ & $\begin{array}{l}0.30 *(0.09- \\
0.96)\end{array}$ & $\begin{array}{l}0.14 * \star \\
0.46)\end{array}$ & $\begin{array}{l}3.90 * \star \star \\
6.28)\end{array}$ & $\begin{array}{l}1.19(0.68- \\
2.10)\end{array}$ \\
\hline \multicolumn{7}{|l|}{ Household size } \\
\hline $1-4$ RC & 1 & 1 & 1 & 1 & 1 & 1 \\
\hline $5-6$ & $\begin{array}{l}0.69 \star \star \star \\
0.850\end{array}$ & $\begin{array}{l}0.82(0.66- \\
1.02)\end{array}$ & $\begin{array}{l}0.69 * *(0.54- \\
0.88)\end{array}$ & $\begin{array}{l}0.74 *(0.58- \\
0.96)\end{array}$ & $\begin{array}{l}0.89(0.73- \\
1.08)\end{array}$ & $\begin{array}{l}1.03 \text { (0.83- } \\
1.27)\end{array}$ \\
\hline $7+$ & $\begin{array}{l}0.58 * \star \star \\
0.70)\end{array}$ & $\begin{array}{l}0.65^{\star \star \star}(0.52- \\
0.80)\end{array}$ & $\begin{array}{l}0.82(0.65- \\
1.02)\end{array}$ & $\begin{array}{l}0.90(0.71- \\
1.15)\end{array}$ & $\begin{array}{l}1.08(0.89- \\
1.29)\end{array}$ & $\begin{array}{l}1.22(0.99- \\
1.49)\end{array}$ \\
\hline
\end{tabular}

The association between background characteristics of male adolescents and multiple sexual partnerships is presented in Table 3 . The odds of having multiple sexual behaviour increases as age increased in all three countries surveyed. After adjusting for all the other variables, male respondents in the 20 to 24 age category were significantly likely to have multiple sexual partners compared to those aged 15 to 19 years of Ghana (AOR $=4.58,95 \% \mathrm{Cl}$ : 3.40-6.16), Rwanda (AOR $=2.72,95 \% \mathrm{Cl}: 2.04-3.68)$ and South Africa (AOR $=4.56,95 \%$ $\mathrm{Cl}$ :3.33-6.24). Again, male adolescents with employment in South Africa were $57 \%$ less likely to engage in multiple sexual partnerships unlike those in Ghana and Rwanda with $63 \%$ and $60 \%$ likelihood. Education was found to be associated with multiple sexual partnerships among male adolescents in South Africa and Ghana at 2.26 and 1.28 odds significantly likely to have multiple sexual partners of those with secondary education attainment. Meanwhile, male adolescents from a household size of 5 to 6 in all the countries were unlikely to have multiple sexual partners compared to those from 1 to 4 household members. 
Table 3

Odds Ratios Multiple sexual Partners by Selected Background Characteristics (Males)

\begin{tabular}{|c|c|c|c|c|c|c|}
\hline & \multicolumn{2}{|l|}{ Ghana } & \multicolumn{2}{|l|}{ Rwanda } & \multicolumn{2}{|l|}{ South Africa } \\
\hline & \multicolumn{2}{|l|}{ Male } & \multicolumn{2}{|l|}{ Male } & \multicolumn{2}{|l|}{ Male } \\
\hline & OR & aOR & OR & aOR & OR & aOR \\
\hline \multicolumn{7}{|l|}{ Respondent age } \\
\hline 15-19 RC & 1 & 1 & 1 & 1 & 1 & 1 \\
\hline $20-24$ & $\begin{array}{l}6.37 * \star \star \\
8.16)\end{array}$ & $\begin{array}{l}4.58^{\star \star \star}(3.40- \\
6.16)\end{array}$ & $\begin{array}{l}3.42^{\star \star \star}(2.62- \\
4.47)\end{array}$ & $\begin{array}{l}2.72^{\star \star \star}(2.04- \\
3.63)\end{array}$ & $\begin{array}{l}0.14 * \star * \\
0.18)\end{array}$ & $\begin{array}{l}4.56 * \star \star(3.33- \\
6.24)\end{array}$ \\
\hline \multicolumn{7}{|l|}{ Employment status } \\
\hline No RC & 1 & 1 & 1 & 1 & 1 & 1 \\
\hline yes & $\begin{array}{l}3.47 \star \star \star \\
4.47)\end{array}$ & $\begin{array}{l}2.63^{\star \star}(1.42- \\
4.88)\end{array}$ & $\begin{array}{l}1.98^{\star \star \star}(1.47- \\
2.67)\end{array}$ & $\begin{array}{l}1.60(0.60- \\
4.25\end{array}$ & $\begin{array}{l}3.76 \star \star \star \star \\
5.54)\end{array}$ & $\begin{array}{l}0.57(0.25- \\
1.28)\end{array}$ \\
\hline \multicolumn{7}{|c|}{ Respondent education attainment } \\
\hline $\begin{array}{l}\text { Primary and less } \\
\text { education RC }\end{array}$ & 1 & 1 & 1 & 1 & 1 & 1 \\
\hline Secondary & $\begin{array}{l}1.58^{\star \star}(1.18- \\
2.10)\end{array}$ & $\begin{array}{l}1.28^{*}(0.89- \\
1.85)\end{array}$ & $\begin{array}{l}1.00(0.77- \\
1.31)\end{array}$ & $\begin{array}{l}0.82(0.60- \\
1.11)\end{array}$ & $\begin{array}{l}2.86^{\star \star \star}(2.04- \\
3.98)\end{array}$ & $\begin{array}{l}2.26 \text { *** }(1.55- \\
3.28)\end{array}$ \\
\hline Higher & $\begin{array}{l}4.09 * * \star(2.29- \\
7.32)\end{array}$ & $\begin{array}{l}1.73^{\star}(0.83- \\
3.60)\end{array}$ & $\begin{array}{l}0.30 *(0.09- \\
3.76)\end{array}$ & $\begin{array}{l}0.84(0.39- \\
1.78)\end{array}$ & $\begin{array}{l}25.69 * \star \star \\
85.87)\end{array}$ & $\begin{array}{l}5.88(1.59- \\
21.70)\end{array}$ \\
\hline \multicolumn{7}{|l|}{ Household size } \\
\hline 1 - 4 RC & 1 & 1 & 1 & 1 & 1 & 1 \\
\hline 5 to 6 & $\begin{array}{l}0.43^{\star \star \star}(0.32- \\
0.58)\end{array}$ & $\begin{array}{l}0.67 *(0.48- \\
0.94)\end{array}$ & $\begin{array}{l}0.63^{\star \star \star}(0.46- \\
0.87)\end{array}$ & $\begin{array}{l}0.79(0.56- \\
1.10)\end{array}$ & $\begin{array}{l}0.67 *(0.50- \\
0.99)\end{array}$ & $\begin{array}{l}0.83(0.59- \\
1.14)\end{array}$ \\
\hline $7+$ & $\begin{array}{l}0.44^{\star \star \star}(0.33- \\
0.58)\end{array}$ & $\begin{array}{l}0.68 *(0.49- \\
0.93)\end{array}$ & $\begin{array}{l}0.83(0.61- \\
1.11)\end{array}$ & $\begin{array}{l}1.04(0.76- \\
1.43)\end{array}$ & $\begin{array}{l}0.76 *(0.58- \\
0.99)\end{array}$ & $\begin{array}{l}0.87(0.64- \\
1.18)\end{array}$ \\
\hline
\end{tabular}

The association between background characteristics of female adolescents and age at first sex is presented in Table 4. The odds of age at first sex among female adolescents increased as age increased in all the three countries surveyed. After adjusting for all the other variables, female respondents in the 20 to 24 aged category were significantly associated with age at first sex compared to those at ages 15 to 19 years of Ghana (AOR $=6.38,95 \% \mathrm{Cl}: 5.07-8.04)$, Rwanda (AOR $=3.32,95 \% \mathrm{Cl}$ : 0.84-3.87) and South Africa (AOR $=10.12,95 \%$ $\mathrm{Cl}: 7.96-12.87)$. Education was found to be associated with age at first sex among female adolescents in South Africa and Ghana at 1.45 and 1.22 times odds among those with secondary education attainment, only those in Rwanda showed no association at the age at first sex. However, there was no association with age at first sex with those from a household of 5 to 6 members in Ghana. There was an association with age at first sex in Rwanda and South Africa among those from a household size of 5 to 6 members. 
Table 4

Odds Ratios of Age at First Sex by Selected Background Characteristics (Females)

\begin{tabular}{|c|c|c|c|c|c|c|}
\hline & \multicolumn{2}{|l|}{ Ghana } & \multicolumn{2}{|l|}{ Rwanda } & \multicolumn{2}{|l|}{ South Africa } \\
\hline & \multicolumn{2}{|l|}{ Female } & \multicolumn{2}{|l|}{ Female } & \multicolumn{2}{|l|}{ Female } \\
\hline & OR & aOR & OR & aOR & OR & aOR \\
\hline \multicolumn{7}{|l|}{ Respondent age } \\
\hline 15-19 RC & 1 & 1 & 1 & 1 & 1 & 1 \\
\hline $20-24$ & $\begin{array}{l}6.38^{\star * \star}(5.26- \\
7.73)\end{array}$ & $\begin{array}{l}6.38 * * \star(5.07- \\
8.04)\end{array}$ & $\begin{array}{l}3.27 * \star \star \\
3.78)\end{array}$ & $\begin{array}{l}3.32^{\star \star \star}(0.84- \\
3.87)\end{array}$ & $\begin{array}{l}11.69 * \star \star \\
14.67)\end{array}$ & $\begin{array}{l}10.12^{\star \star \star}(7.96- \\
12.87)\end{array}$ \\
\hline \multicolumn{7}{|c|}{ Employment status } \\
\hline No RC & 1 & 1 & 1 & 1 & 1 & 1 \\
\hline Yes & $\begin{array}{l}2.07 * * *(1.75- \\
2.44)\end{array}$ & $\begin{array}{l}0.71(0.42- \\
1.20)\end{array}$ & $\begin{array}{l}1.83^{\star \star \star}(1.57- \\
2.11)\end{array}$ & $\begin{array}{l}1.05(0.81- \\
1.36)\end{array}$ & $\begin{array}{l}4.60 \star \star \star \\
6.90)\end{array}$ & $1.53(0.62-3.78)$ \\
\hline \multicolumn{7}{|c|}{ Respondent education attainment } \\
\hline $\begin{array}{l}\text { Primary or less } \\
\text { education RC }\end{array}$ & 1 & 1 & 1 & 1 & 1 & 1 \\
\hline Secondary & $\begin{array}{l}1.44^{\star \star \star}(1.19- \\
1.74)\end{array}$ & $\begin{array}{l}1.22(0.97- \\
1.53)\end{array}$ & $\begin{array}{l}0.71 \star \star \star \star \\
0.82)\end{array}$ & $\begin{array}{l}0.66 * * \star(0.56- \\
0.78)\end{array}$ & $\begin{array}{l}1.64^{\star \star}(1.18- \\
2.27)\end{array}$ & $\begin{array}{l}1.45^{\star}(0.99- \\
2.11)\end{array}$ \\
\hline Higher & $\begin{array}{l}1.92^{\star \star}(1.25- \\
2.97)\end{array}$ & $\begin{array}{l}0.47(0.28- \\
0.82)\end{array}$ & $\begin{array}{l}0.69(0.39- \\
1.23)\end{array}$ & $\begin{array}{l}0.32^{\star \star \star}(0.17- \\
0.58)\end{array}$ & $\begin{array}{l}3.89 \star \star \star \\
6.39)\end{array}$ & $0.82(0.44-1.54)$ \\
\hline \multicolumn{7}{|l|}{ Household size } \\
\hline 1 - 4 RC & 1 & 1 & 1 & 1 & 1 & 1 \\
\hline $5-6$ & $\begin{array}{l}0.67^{\star * \star}(0.56- \\
0.81\end{array}$ & $\begin{array}{l}0.82(0.66- \\
1.02)\end{array}$ & $\begin{array}{l}0.92(0.77- \\
1.10)\end{array}$ & $\begin{array}{l}1.01(0.84- \\
1.23)\end{array}$ & $0.87(0.72-1.06)$ & $1.01(0.80-1.27)$ \\
\hline $7+$ & $\begin{array}{l}0.53^{\star \star \star}(1.27- \\
1.66)\end{array}$ & $\begin{array}{l}0.60 * \star \star \\
0.75)\end{array}$ & $\begin{array}{l}0.96(0.80- \\
1.13)\end{array}$ & $\begin{array}{l}1.11(0.92- \\
1.34)\end{array}$ & $1.13(0.93-1.36)$ & $\begin{array}{l}1.30 * *(1.04- \\
1.64)\end{array}$ \\
\hline
\end{tabular}

The association between background characteristics of male adolescents and age at first sex is presented in Table 5. The table below shows that the odds of age at first sex among male adolescents increase as age increased in all the three countries surveyed. After adjusting for all the other variables, male respondents in the 20 to 24 age category were significantly associated with age at first sex compared to those aged 15 to 19 years of Ghana (AOR $=6.23,95 \% \mathrm{Cl}$ : 4.67-8.32), Rwanda (AOR = 2.49, 95\% Cl: 2.03-3.06) and South Africa (AOR $=6.30,95 \% \mathrm{Cl}: 4.37-9.10)$. Also, male adolescents with employment in Ghana and Rwanda were $85 \%$ and $32 \%$ more likely to be associated with age at first sex unlike those in South Africa with $84 \%$ unlikelihood to be associated with age at first sex than those without any employment. Education was found to be associated with age at first sex among male adolescents in South Africa and Ghana at 2.48 and 1.52 odds among those with secondary education attainment, only those in Rwanda showed no association at an age at first sex. There was no association with age at first sex with household size in all the three countries surveyed among male adolescents. 
Table 5

Odds Ratios of Age at First Sex by Selected Background Characteristics (Males)

\begin{tabular}{|c|c|c|c|c|c|c|}
\hline & \multicolumn{2}{|l|}{ Ghana } & \multicolumn{2}{|l|}{ Rwanda } & \multicolumn{2}{|l|}{ South Africa } \\
\hline & \multicolumn{2}{|l|}{ Male } & \multicolumn{2}{|l|}{ Male } & \multicolumn{2}{|l|}{ Male } \\
\hline & OR & aOR & OR & aOR & OR & aOR \\
\hline \multicolumn{7}{|l|}{ Respondent age } \\
\hline 15-19 RC & 1 & 1 & 1 & 1 & 1 & 1 \\
\hline $20-24$ & $\begin{array}{l}8.53^{\star * *}(6.68- \\
10.88)\end{array}$ & $\begin{array}{l}6.23^{\star \star \star}(4.67- \\
8.32)\end{array}$ & $\begin{array}{l}3.05^{\star \star \star}(2.53- \\
3.68)\end{array}$ & $\begin{array}{l}2.49 \star \star \star \\
3.06)\end{array}$ & $\begin{array}{l}9.88 * \star * \\
13.68)\end{array}$ & $\begin{array}{l}6.30 \star \star \star \\
9.10)\end{array}$ \\
\hline \multicolumn{7}{|c|}{ Employment status } \\
\hline No RC & 1 & 1 & 1 & 1 & 1 & 1 \\
\hline Yes & $\begin{array}{l}2.94^{\star * *}(2.35- \\
3.67)\end{array}$ & $\begin{array}{l}1.85^{\star}(1.05- \\
3.27)\end{array}$ & $\begin{array}{l}1.98^{\star \star \star}(1.62- \\
2.43)\end{array}$ & $\begin{array}{l}1.32(0.67- \\
2.58)\end{array}$ & $\begin{array}{l}5.11 * \star \star(3.17- \\
8.24)\end{array}$ & $0.84(0.34-2.08)$ \\
\hline \multicolumn{7}{|c|}{ Respondent education attainment } \\
\hline $\begin{array}{l}\text { Primary or less } \\
\text { education RC }\end{array}$ & 1 & 1 & 1 & 1 & 1 & 1 \\
\hline Secondary & $\begin{array}{l}1.86^{\star \star \star}(1.43- \\
2.42)\end{array}$ & $\begin{array}{l}1.52 * 1.07- \\
2.15)\end{array}$ & $\begin{array}{l}1.07(0.89- \\
1.30)\end{array}$ & $\begin{array}{l}0.99 * * \star \\
1.25)\end{array}$ & $\begin{array}{l}3.17 \star \star \star \\
4.40)\end{array}$ & $\begin{array}{l}2.48 * \star \star \\
3.60)\end{array}$ \\
\hline Higher & $\begin{array}{l}5.66^{\star \star \star}(3.06- \\
10.45)\end{array}$ & $\begin{array}{l}1.59(0.74- \\
3.40)\end{array}$ & $\begin{array}{l}1.79 *(1.03- \\
3.09\end{array}$ & $\begin{array}{l}0.94(0.50- \\
1.74)\end{array}$ & $\begin{array}{l}63.16^{\star \star *}(8.53- \\
46.70)\end{array}$ & $\begin{array}{l}10.01 * *(1.28- \\
84.40)\end{array}$ \\
\hline \multicolumn{7}{|l|}{ Household size } \\
\hline $1-4 \mathrm{RC}$ & 1 & 1 & 1 & 1 & 1 & 1 \\
\hline $5-6$ & $\begin{array}{l}0.40 * * *(0.31- \\
0.53)\end{array}$ & $\begin{array}{l}0.61^{\star *}(0.45- \\
0.84)\end{array}$ & $\begin{array}{l}0.78 *(0.62- \\
0.98)\end{array}$ & $\begin{array}{l}0.96(0.75- \\
1.22)\end{array}$ & $\begin{array}{l}0.68 * \star \\
0.92)\end{array}$ & $0.86(0.61-1.20)$ \\
\hline $7+$ & $\begin{array}{l}0.37 * \star \star \\
0.48)\end{array}$ & $\begin{array}{l}0.54 \star \star \star \\
0.74)\end{array}$ & $\begin{array}{l}0.74(0.59- \\
0.92)\end{array}$ & $\begin{array}{l}0.89(0.70- \\
1.13)\end{array}$ & $\begin{array}{l}0.74 *(0.50- \\
0.99)\end{array}$ & $0.87(0.63-1.20)$ \\
\hline
\end{tabular}

Table 6 presents the results of the multilevel logistics regression analysis of the risk of engaging in multiple sexual partnerships in all the countries surveyed among female adolescents. The results indicate that the test statistics was significant, thus it shows evidence that the between-neighbourhoods variance is non-zero, as was revealed on the variance partition coefficient (VPC) values. Therefore, the total variance in the risk of engaging in multiple sexual partners among female adolescents as a result of differences between neighbourhoods ranged from 5\% (Ghana) to 10\% (Rwanda) and 5\% (South Africa). It was discovered that the variations decreased after controlling for individual (model 2) and neighbourhoods (model 3). More so, there were significant compositional effects as shown in Table 6. For instance, female adolescents living in high neighbourhood poverty significantly increased the odds of multiple sexual partnerships by $54 \%$ (South Africa) and 3\% (Rwanda). There were 99\% lower odds of engaging in multiple sexual partnerships among female adolescents living in high neighbourhood poverty in Ghana compared to those living in low neighbourhoods. Additionally, the results revealed that there was $14 \%$ and $1 \%$ (Ghana) for those without regular access to community media to have multiple sexual partners compared to those with no access. However, South Africa and Rwanda revealed lower odds of engaging in having multiple sexual partners among female adolescents with regular access to the community media.

Furthermore, the results showed strong significant effects with community occupation. For instance, female adolescents in agriculture increased the odds of having multiple sexual partners by $16 \%$ (South Africa), $3 \%$ (Rwanda) and 45\% (Ghana). Again, community education increased the odds of engaging in multiple sexual partners among female adolescents by 53\% (South Africa), to 4\% (Ghana). Meanwhile, the higher the community education in Rwanda, the lower the odds of engaging in multiple sexual partners among female adolescents. The results from the three countries indicated that female adolescents living in rural areas had a higher level of exposure to engaging in multiple sexual partners in South Africa and Ghana, although the result was not significant. However, Rwanda had significantly lower odds of engaging in multiple sexual partners among female adolescents residing in rural areas compared to those residing in urban areas. 
Table 6

Multilevel Logistic Regression analysis of multiple sexual partnerships among Female Adolescent

\begin{tabular}{|c|c|c|c|c|c|c|c|}
\hline \multicolumn{3}{|l|}{ Model1: Null Model } & \multicolumn{3}{|c|}{ Model 2: Individual } & \multicolumn{2}{|c|}{ Model 3: Neighbourhood } \\
\hline Rwanda & $\begin{array}{l}\text { South } \\
\text { Africa }\end{array}$ & Ghana & Rwanda & $\begin{array}{l}\text { South } \\
\text { Africa }\end{array}$ & Ghana & Rwanda & $\begin{array}{l}\text { South } \\
\text { Africa }\end{array}$ \\
\hline \multicolumn{8}{|l|}{ Respondent age } \\
\hline $15-19$ & & 1 & 1 & 1 & & & \\
\hline $20-24$ & & $4.08 * \star \star *$ & $3.14^{\star * *}$ & $6.42^{\star \star \star}$ & & & \\
\hline \multicolumn{8}{|l|}{ Employment status } \\
\hline No & & 1 & 1 & 1 & & & \\
\hline Yes & & $1.54 * \star \star$ & 1.37 & $1.43^{*}$ & & & \\
\hline \multicolumn{8}{|l|}{ Respondent education attainment } \\
\hline Primary and less education & & 1 & 1 & 1 & & & \\
\hline Secondary & & 1.15 & $0.79 *$ & $1.57^{\star}$ & & & \\
\hline Higher & & 0.18 & 0.14 ** & 1.46 & & & \\
\hline \multicolumn{8}{|l|}{ Household size } \\
\hline $1-4$ & & 1 & 1 & 1 & & & \\
\hline $5-6$ & & 0.84 & $0.73^{*}$ & 1.04 & & & \\
\hline $7+$ & & $0.66^{\star \star}$ & 0.91 & 1.24 & & & \\
\hline \multicolumn{8}{|l|}{ Neighbourhood poverty } \\
\hline Low & & & & & 1 & 1 & 1 \\
\hline High & & & & & 0.99 & 1.03 & $1.54^{\star \star \star}$ \\
\hline \multicolumn{8}{|l|}{ Community media access } \\
\hline No access & & & & & 1 & 1 & 1 \\
\hline Not regular & & & & & 1.14 & 0.86 & 0.72 \\
\hline Regularly & & & & & 1.01 & $0.70 *$ & 0.84 \\
\hline \multicolumn{8}{|l|}{ Community occupation } \\
\hline Not working & & & & & 1 & 1 & 1 \\
\hline Professionals & & & & & $2.13^{\star \star \star}$ & 2.01 & 1.47 \\
\hline Sales/unspecified & & & & & $2.55^{\star \star \star}$ & $2.38 * * *$ & $5.15^{\star}$ \\
\hline Agriculture & & & & & $1.45^{\star \star}$ & $2.03^{\star \star *}$ & $11.16^{\star \star *}$ \\
\hline Manual & & & & & $3.94^{\star \star \star}$ & $3.39 * \star \star$ & $2.58 * \star \star$ \\
\hline \multicolumn{8}{|l|}{ Community education } \\
\hline Low & & & & & 1 & 1 & 1 \\
\hline High & & & & & $2.04^{\star \star \star}$ & 0.95 & $3.53^{\star \star \star}$ \\
\hline \multicolumn{8}{|l|}{ Place of residence } \\
\hline Urban & & & & & 1 & 1 & 1 \\
\hline Rural & & & & & $1.37 * \star$ & $0.43^{\star \star *}$ & 1.13 \\
\hline
\end{tabular}

Source: (DHS) Ghana 2014; Rwanda 2015 and South Africa 2016 


\begin{tabular}{|c|c|c|c|c|c|c|c|c|c|}
\hline \multicolumn{4}{|c|}{ Model1: Null Model } & & \multicolumn{3}{|c|}{ Model 2: Individual } & \multicolumn{2}{|c|}{ Model 3: Neighbourhood } \\
\hline $\begin{array}{l}\text { Random } \\
\text { effects }\end{array}$ & & Null & & & Individual & & & Neighbour & \\
\hline $\begin{array}{l}\text { Community } \\
\text { variance } \\
\text { (SE) }\end{array}$ & 0.018756 & 0.60848 & 0.410184 & 0.6944607 & 0.711216 & 0.419383 & 0.699517 & 0.534234 & 0.460199 \\
\hline $\begin{array}{l}\text { VPC=ICC } \\
(\%)\end{array}$ & 0.05 & 0.10 & 0.05 & 0.13 & 0.13 & 0.05 & 0.13 & 0.08 & 0.06 \\
\hline $\begin{array}{l}\text { Explained } \\
\text { variation } \\
\text { PCV (\%) }\end{array}$ & Ref & Ref. & Ref. & -9.65 & -31.74 & -4.31 & -11.05 & 21.09 & -24.31 \\
\hline $\begin{array}{l}\text { Log- } \\
\text { Likelihood }\end{array}$ & -1792.84 & -1483.68 & -1792.84 & -1479.999 & -1395.99 & -1549.95 & -1549.37 & -1433.16 & -1674.63 \\
\hline \multicolumn{10}{|c|}{ Model fit statistics } \\
\hline AIC & 3589.682 & 2971.352 & 3589.682 & 2975.997 & 2807.974 & 3115.891 & 3120.745 & 2888.313 & 3371.264 \\
\hline BIC & 3601.424 & 2984.027 & 3601.424 & 3022.486 & 2858.642 & 3162.861 & 3184.7 & 2957.987 & 3435.848 \\
\hline
\end{tabular}

The results presented in Table 7 reveals the risk of engaging in multiple sexual partnerships among male adolescents in all the countries surveyed. The results indicate that the test statistics was significant, hence, it indicates evidence that the between-neighbourhoods variance is non-zero, as was revealed on the variance partition coefficient (VPC) values. Therefore, the total variance in the risk of engaging in multiple sexual partners among male adolescents as a result of differences that existed between neighbourhoods ranged from $15 \%$ (Ghana) to 11\% (Rwanda) and 14\% (South Africa). It was discovered that the variations decreased after controlling for individual (model 2) and neighbourhoods (model 3) characteristics. More so, there were significant compositional effects as observed in Table 7 below. For example, male adolescents living in high neighbourhood poverty significantly increased the odds of multiple sexual partnerships by $45 \%$ (South Africa), to 55\% (Rwanda) and 45\% (Ghana) compared to those living in low neighbourhoods. Additionally, the results revealed community media access significantly increased the odds of multiple sexual partnerships among male adolescents in Ghana and Rwanda among those with regular access. Also, there was a 63\% (Ghana), to 48\% (Rwanda) and 33\% increase in the odds among male adolescents without regular access to community media, though not significant. Furthermore, the results showed strong significant effects with community occupation. For instance, male adolescents in the category of professionals significantly increased the odds of having multiple sexual partners by $60 \%$ (South Africa), $23 \%$ (Rwanda) and $97 \%$ (Ghana).

Again, community education significantly increased the odds of engaging in multiple sexual partners among male adolescents by $23 \%$ (South Africa), to $20 \%$ (Ghana). Meanwhile, the higher the community education in Rwanda, the lower the odds of engaging in multiple sexual partners among male adolescents. The results from the three countries indicated that male adolescents living in rural areas had a higher level of exposure to engaging in multiple sexual partners in South Africa, Rwanda and Ghana, although the result was not significant in South Africa. 
Table 7

Multilevel Logistic regression analysis of multiple sexual partnerships among Male Adolescent

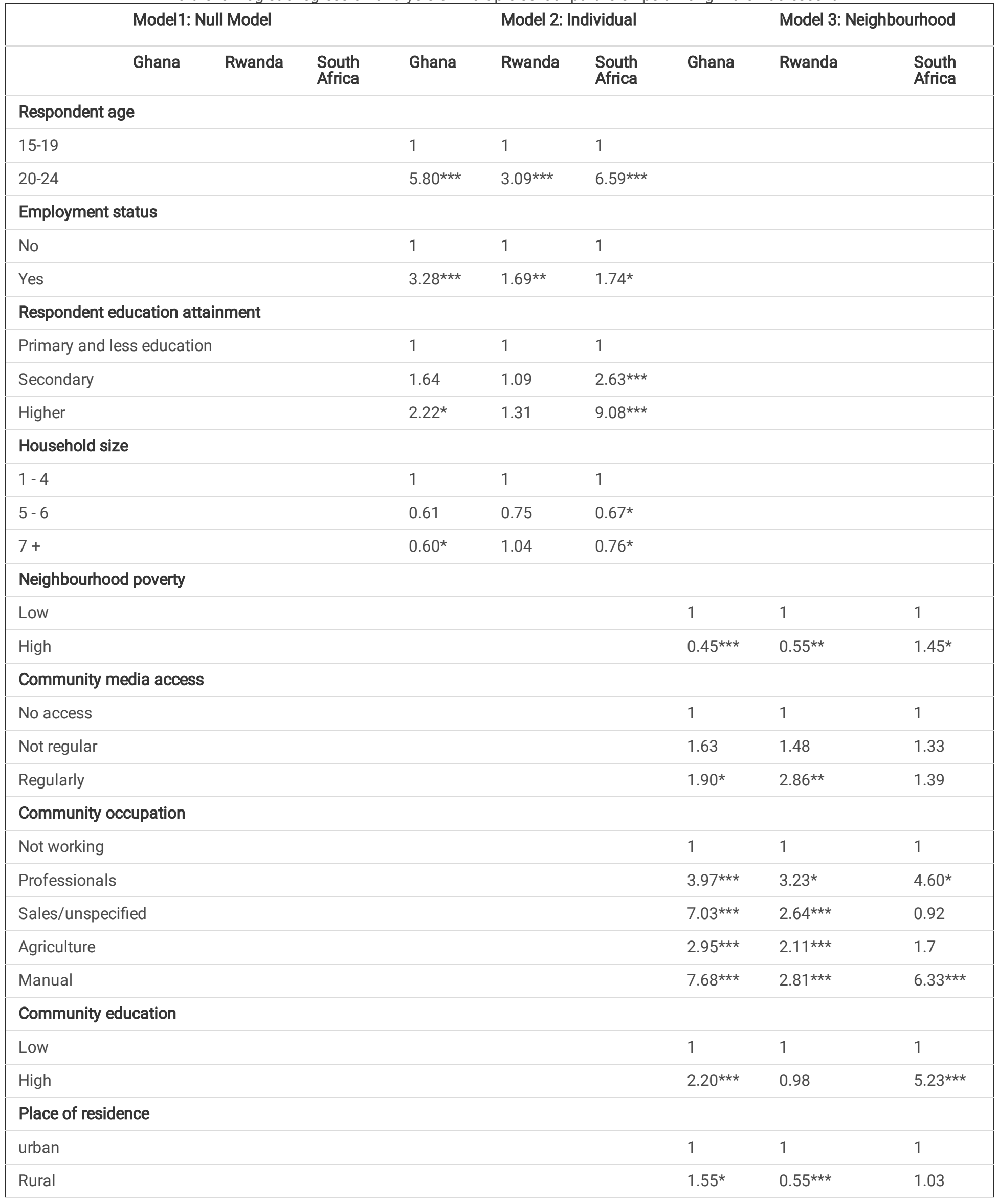

Source: (DHS) Ghana 2014; Rwanda 2015 and South Africa 2016 


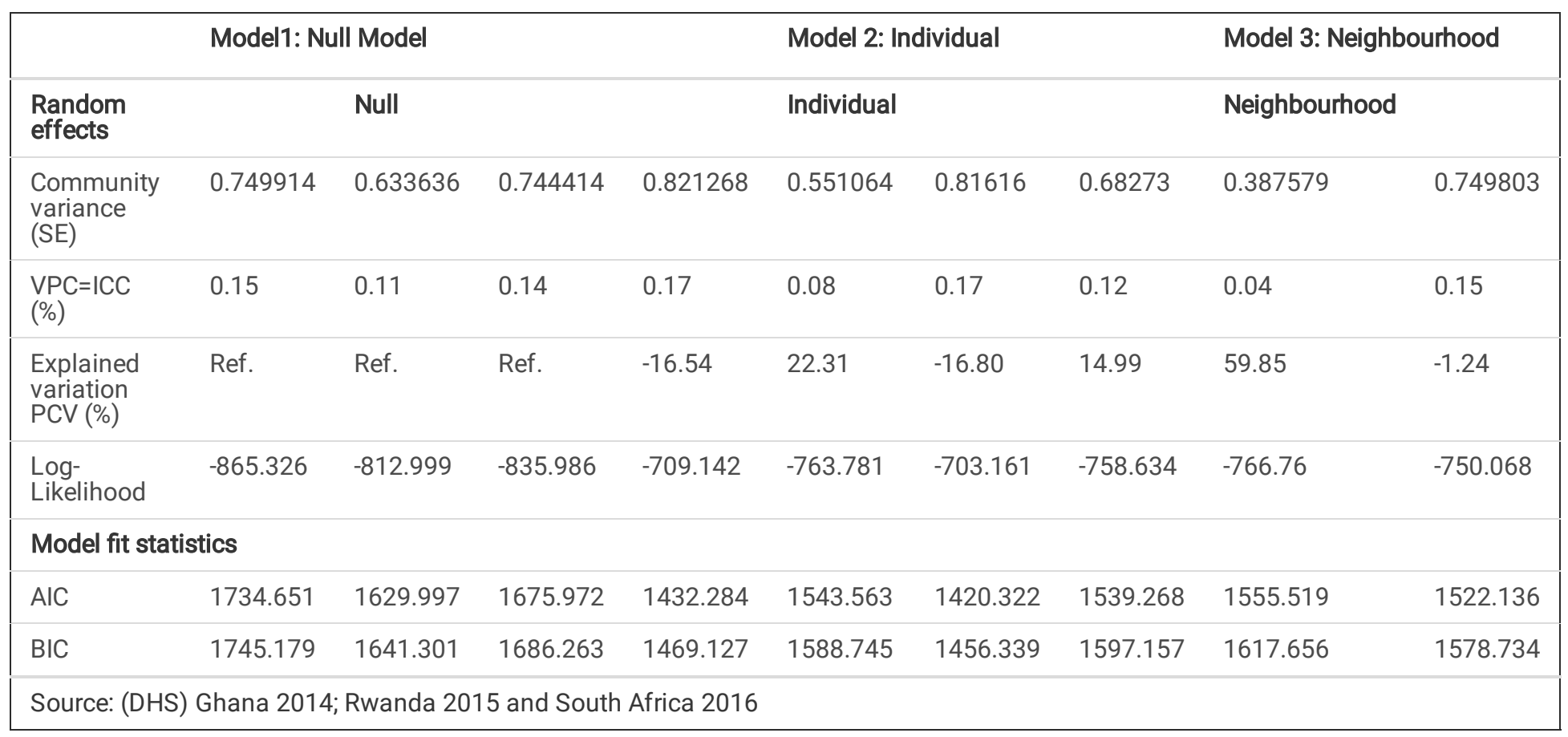

In Table 8 below, the results of age at first sex in all the countries surveyed among female adolescents is presented. The test of statistics was significant, as the result of variance partition coefficient (VPC) values indicated that the between-neighbourhoods variance is non-zero. Therefore, the total variance in age at first sex among female adolescents as a result of differences that existed between neighbourhoods ranged from 15\% (Ghana) to 11\% (Rwanda) and 14\% (South Africa). After controlling for individual (model 2) and neighbourhoods (model 3) characteristics, the variations decreased.

The results indicate that there were significant compositional effects as shown in the results displayed in Table 8 below. For instance, adolescent females living in high neighbourhood poverty in South Africa significantly increased the age of first sex at $81 \%$. In addition, there was an increased odds of $8 \%$ in Ghana, though not significant, compared to female adolescents in Rwanda with a lower odds of age at first sex at $98 \%$.

Among all the countries, results revealed that community media access significantly reduced the odds of age at first sex, except in Ghana where female adolescents had an increased likelihood of age at first sex among those without regular access to community media, though not significant. Furthermore, the results showed strong significant effects with community occupation. For instance, female adolescents in all the categories of occupations significantly increased the odds of age at first sex. Again, community education significantly increased the odds of age at first sex among female adolescents by $50 \%$ (South Africa), to $46 \%$ (Ghana). Meanwhile, the higher the community education in Rwanda, the lower the odds of age at first sex among female adolescents. The results from the three countries indicated that female adolescents living in rural areas had a higher level of exposure to age at first sex in South Africa, Rwanda and Ghana, although the results were not significant in South Africa. 
Table 8

Multilevel Logistic regression analysis of Age at First Sex among Female Adolescent

\begin{tabular}{|c|c|c|c|c|c|c|c|c|}
\hline & \multicolumn{3}{|c|}{ Model 1: Null } & \multicolumn{3}{|c|}{ Model 2: Individual } & \multicolumn{2}{|c|}{ Model 3: Neighbourhood } \\
\hline Ghana & Rwanda & $\begin{array}{l}\text { South } \\
\text { Africa }\end{array}$ & Ghana & Rwanda & $\begin{array}{l}\text { South } \\
\text { Africa }\end{array}$ & Ghana & Rwanda & $\begin{array}{l}\text { South } \\
\text { Africa }\end{array}$ \\
\hline \multicolumn{9}{|l|}{ Respondent age } \\
\hline $15-19$ & & & 1 & 1 & 1 & & & \\
\hline $20-24$ & & & $7.96 * \star \star$ & $3.59 * * \star$ & $13.47 * \star \star$ & & & \\
\hline \multicolumn{9}{|l|}{ Employment status } \\
\hline No & & & 1 & 1 & 1 & & & \\
\hline Yes & & & $1.51 * \star \star$ & $1.47 * \star \star$ & $1.77 *$ & & & \\
\hline \multicolumn{9}{|l|}{ Respondent education attainment } \\
\hline Primary and less education & & & 1 & 1 & 1 & & & \\
\hline Secondary & & & 1.14 & $0.62^{\star \star \star}$ & 1.43 & & & \\
\hline Higher & & & $0.41 * \star \star$ & $0.32^{\star \star \star}$ & 0.99 & & & \\
\hline \multicolumn{9}{|l|}{ Household size } \\
\hline $1-4$ & & & 1 & 1 & 1 & & & \\
\hline $5-6$ & & & 0.85 & 1.02 & 1.06 & & & \\
\hline $7+$ & & & $0.62^{\star \star \star}$ & 1.09 & 1.38 & & & \\
\hline \multicolumn{9}{|l|}{ Neighbourhood poverty } \\
\hline Low & & & & & & 1 & 1 & 1 \\
\hline High & & & & & & 1.08 & 0.98 & $1.81^{* * *}$ \\
\hline \multicolumn{9}{|l|}{ Community media access } \\
\hline No access & & & & & & 1 & 1 & 1 \\
\hline Not regular & & & & & & 1.18 & 0.85 & $0.74^{\star}$ \\
\hline Regularly & & & & & & 1.03 & 0.71 & $0.81^{\star}$ \\
\hline \multicolumn{9}{|l|}{ Community occupation } \\
\hline Not working & & & & & & 1 & 1 & 1 \\
\hline Professionals & & & & & & $2.13^{\star \star \star}$ & $2.09 *$ & $1.80 *$ \\
\hline Sales/unspecified & & & & & & $2.72^{\star \star \star}$ & $2.53 * \star \star$ & 0.11 \\
\hline Agriculture & & & & & & $1.36^{\star}$ & $2.19 * \star \star$ & $3.73^{\star \star *}$ \\
\hline Manual & & & & & & $4.97 * \star \star$ & $2.50 * \star \star$ & 8.24 \\
\hline \multicolumn{9}{|l|}{ Community education } \\
\hline Low & & & & & & 1 & 1 & \\
\hline High & & & & & & $2.63^{\star \star \star}$ & $0.46^{\star \star \star}$ & $4.50 * \star *$ \\
\hline
\end{tabular}

Source: (DHS) Ghana 2014; Rwanda 2015 and South Africa 2016 


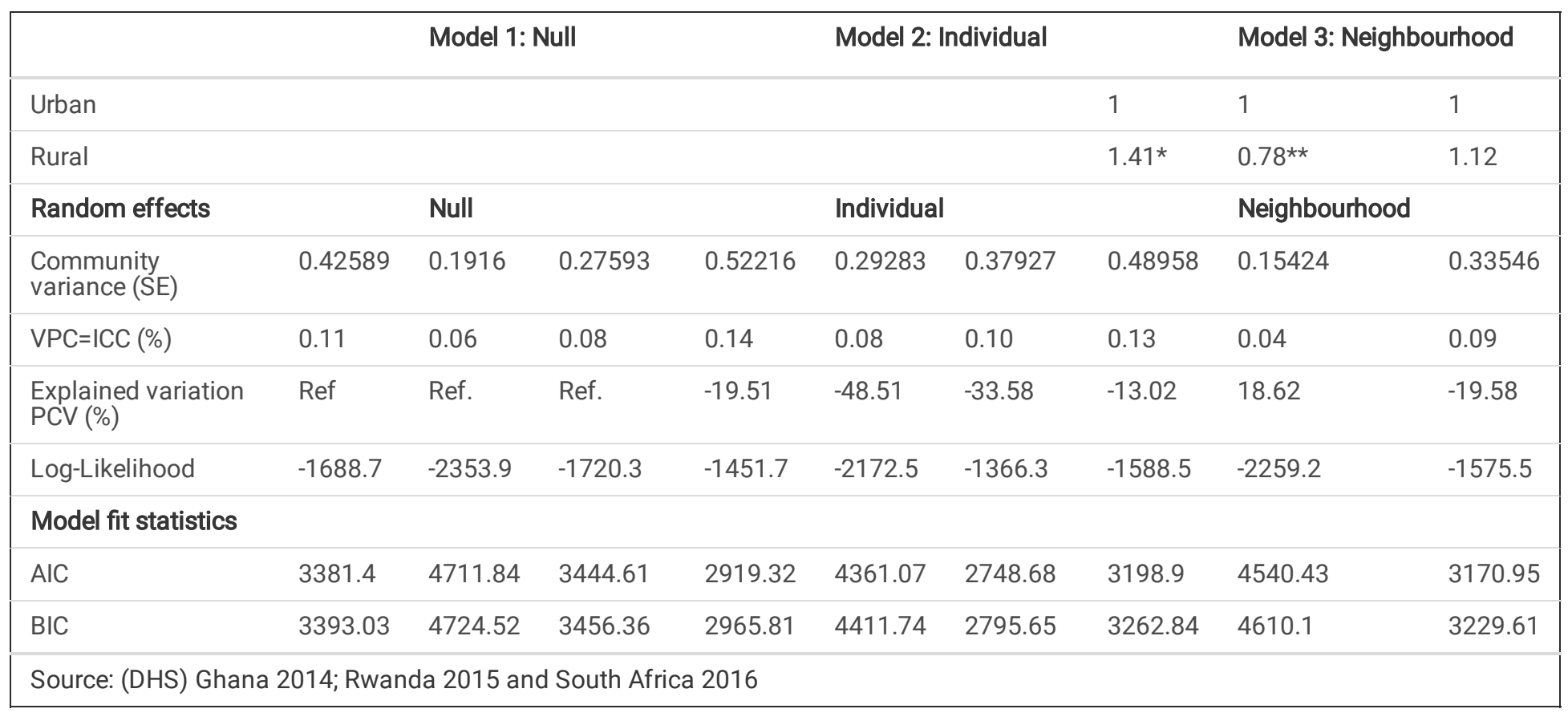

The results of age at first sex in all the countries surveyed among male adolescents are presented in Table 9 below. The test of statistics was significant, as the result of variance partition coefficient (VPC) values indicated that the between-neighbourhoods variance is non-zero. Therefore, the total variance in age at first sex among male adolescents as a result of differences that existed between neighbourhoods ranged from 14\% (Ghana) to 12\% (Rwanda) and 17\% (South Africa). In addition, after controlling for individual (model 2) and neighbourhoods (model 3) characteristics, the variations decreased.

The results further revealed that there were significant compositional effects. For example, adolescent males living in high neighbourhood poverty in South Africa significantly increased the age of first sex by $26 \%$. The results indicate that there was no association in age at first sex in Ghana and Rwanda among females in high neighbourhood poverty compared to those in low neighbourhood poverty. In all the countries, results revealed that community media access significantly increased the odds of age at first sex among those that regularly and not regularly accessed community media, except in Ghana among male adolescents without regular access to community media.

Furthermore, the results showed strong significant effects with community occupation. For instance, male adolescents in all the categories of occupation significantly increased the odds of age at first sex. Again, community education significantly increased the odds of age at first sex among male adolescents by $50 \%$ (South Africa), to $46 \%$ (Ghana). Meanwhile, the higher the community education in Rwanda, the higher the odds of age at first sex among male adolescents, although not significant. The results from the three countries indicated that male adolescents living in rural areas had a higher level of exposure to age at first sex in South Africa and Ghana, although the results were insignificant in South Africa compared to those in Rwanda with $66 \%$ significant lower odds of age at first sex. 
Table 9

Multilevel Logistic analysis of Age at First Sex among Male Adolescent

\begin{tabular}{|c|c|c|c|c|c|c|c|c|}
\hline \multirow[b]{2}{*}{ Ghana } & \multicolumn{3}{|c|}{ Model 1: Null } & \multicolumn{3}{|c|}{ Model 2: Individual } & \multicolumn{2}{|c|}{ Model 3: Neighbourhood } \\
\hline & Rwanda & $\begin{array}{l}\text { South } \\
\text { Africa }\end{array}$ & Ghana & Rwanda & $\begin{array}{l}\text { South } \\
\text { Africa }\end{array}$ & Ghana & Rwanda & $\begin{array}{l}\text { South } \\
\text { Africa }\end{array}$ \\
\hline \multicolumn{9}{|l|}{ Respondent age } \\
\hline 15-19 & & & 1 & 1 & 1 & & & \\
\hline $20-24$ & & & $8.41^{\star \star \star}$ & $2.94^{\star \star \star}$ & $10.07 * \star \star$ & & & \\
\hline \multicolumn{9}{|l|}{ Employment status } \\
\hline No & & & 1 & 1 & 1 & & & \\
\hline Yes & & & 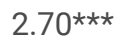 & $1.84^{\star \star \star}$ & 2.24 & & & \\
\hline \multicolumn{9}{|l|}{ Respondent education attainment } \\
\hline Primary and less education & & & 1 & 1 & 1 & & & \\
\hline Secondary & & & $1.98^{\star \star \star}$ & 1.15 & $3.34^{\star \star \star}$ & & & \\
\hline Higher & & & $2.27 *$ & 1.27 & 18.24 & & & \\
\hline \multicolumn{9}{|l|}{ Household size } \\
\hline $1-4$ & & & 1 & 1 & 1 & & & \\
\hline $5-6$ & & & $0.56^{\star \star \star}$ & 0.94 & 0.81 & & & \\
\hline $7+$ & & & $0.48 * \star \star$ & 0.88 & 0.88 & & & \\
\hline \multicolumn{9}{|l|}{ Neighbourhood poverty } \\
\hline Low & & & & & & 1 & 1 & 1 \\
\hline High & & & & & & $0.56^{\star \star \star}$ & 0.7 & 1.26 \\
\hline \multicolumn{9}{|l|}{ Community media access } \\
\hline No access & & & & & & 1 & 1 & 1 \\
\hline Not regular & & & & & & 0.99 & 1.46 & $1.53^{\star}$ \\
\hline Regularly & & & & & & 1.28 & $2.29 * * \star$ & 1.39 \\
\hline \multicolumn{9}{|l|}{ Community occupation } \\
\hline Not working & & & & & & 1 & 1 & 1 \\
\hline Professionals & & & & & & $4.12^{\star \star \star}$ & $2.93^{\star \star}$ & $11.87^{\star}$ \\
\hline Sales/unspecified & & & & & & $6.52^{\star \star \star}$ & $3.14^{\star \star \star}$ & 1.24 \\
\hline Agriculture & & & & & & $2.83^{\star \star \star}$ & $2.19 \star \star \star$ & $2.32^{\star}$ \\
\hline Manual & & & & & & $6.99 * \star \star$ & $3.68 * * \star$ & $7.66^{\star \star \star}$ \\
\hline \multicolumn{9}{|l|}{ Community education } \\
\hline Low & & & & & & 1 & 1 & 1 \\
\hline High & & & & & & $2.83^{\star \star \star}$ & 1.16 & $6.44^{\star \star \star}$ \\
\hline \multicolumn{9}{|l|}{ Place of residence } \\
\hline Urban & & & & & & 1 & 1 & 1 \\
\hline Rural & & & & & & 1.11 & $0.66^{*}$ & 1.09 \\
\hline
\end{tabular}

Source: (DHS) Ghana 2014; Rwanda 2015 and South Africa 2016 


\begin{tabular}{|c|c|c|c|c|c|c|c|c|c|}
\hline & \multicolumn{4}{|c|}{ Model 1: Null } & \multicolumn{3}{|c|}{ Model 2: Individual } & \multicolumn{2}{|c|}{ Model 3: Neighbourhood } \\
\hline \multicolumn{2}{|l|}{ Random effects } & \multicolumn{3}{|l|}{ Null } & \multicolumn{3}{|l|}{ Individual } & \multicolumn{2}{|c|}{ Neighbourhood } \\
\hline $\begin{array}{l}\text { Community } \\
\text { variance (SE) }\end{array}$ & 0.72849 & 0.44826 & 0.66001 & 0.81416 & 0.45336 & 1.04597 & 0.68178 & 0.36022 & 0.75527 \\
\hline VPC=ICC (\%) & 0.14 & 0.12 & 0.17 & 0.17 & 0.12 & 0.24 & 0.12 & 0.10 & 0.19 \\
\hline $\begin{array}{l}\text { Explained variation } \\
\text { PCV }(\%)\end{array}$ & Ref. & Ref. & Ref. & -20.73 & -1.00 & -44.37 & 10.87 & -82.30 & -11.74 \\
\hline Log-Likelihood & -955.39 & -1326.9 & -777.04 & -745.58 & -1241.5 & -625.78 & -837.31 & -1256.4 & -692.81 \\
\hline \multicolumn{10}{|l|}{ Model fit statistics } \\
\hline AIC & 1914.77 & 2657.83 & 1558.08 & 1505.16 & 2499 & 1265.55 & 1696.62 & 2534.84 & 1407.62 \\
\hline $\mathrm{BIC}$ & 1925.3 & 2669.14 & 1568.37 & 1542 & 2544.17 & 1301.57 & 1754.51 & 2596.98 & 1464.22 \\
\hline
\end{tabular}

\section{Discussions}

The purpose of this study was to examine the neighbourhood factors that encourage young people to engage in risky sexual behaviour in three African countries that cut across West, East and Southern African regions. Our analysis of nationally weighted and representative survey data of the three countries found that a high proportion of male and female adolescents that were exposed to the sexual risk behaviours were those below the age of 18 years. Reports of early sexual debut and multiple sexual partnerships have exposed this young productive age cohort to the risk of sexually transmitted infections, including HIV/AIDS. We found that male adolescents were more likely to report the age at which they start having sexual intercourse and multiple sexual partnerships than their female counterparts. These findings are in line with previous observations that revealed that male adolescents tend to indulge in risky sexual behaviours, [35, 36]. The power inequalities embedded in most of the African communities that allow men to have control over women could be attributed to the high engagement of male adolescents in sexual risk-taking. These practices have been in existence for ages and further complicate the issue of sexual and reproductive health rights of young people in Africa especially female adolescents, hence, undermining the efforts by government and non-governmental organizations in curbing diseases associated with sexual risk practices on the continent.

Additionally, the high values of intra-cluster correlations observed in the results emphasize the importance of neighbourhood variables in the engagements of young people in risky sexual behaviour of multiple sexual partnerships and early sexual debut. Earlier research on the impact of communities on youth development showed little attention to the effect of social disorganisation factors on youth transition most especially their sexual risk practices [37,38]. However, our findings established various pathways through which neighbourhood factors influence sexual risk-taking among male and female adolescents in all the countries surveyed. The findings have great implications for STIs prevention in SSA, particularly among young people whose activities might not be monitored as a result of the prevalence of social disorganisation factors in their communities. This is because there is the tendency that the current sexuality education programs, particularly at the community level, are insufficient in addressing variables that predispose young people to engage in sexual risk-taking. Thus, attitudinal change towards positive sexual behaviour becomes problematic.

Unlike previous studies [39, 40,41], our findings reveal that adolescent sexual risk-taking could be compounded as a result of an association between community occupations, poverty and media access. This association may be explained by the possibility that adolescents from a community with high-level occupation employment (e.g., Doctors, Lawyers, Engineers etc.) and residing in a lowpoverty neighbourhood, despite having better media access (e.g., family radio, television, internet, etc.) without a better household control over media use, tend to engage in risky sexual behaviour. This finding was expected considering the proportion of young people found in the neighbourhood with adequate media access without proper control either from their parents or guardians. As a result, while awareness of sexual and reproductive health safety and risk reduction measures such as early sexual debut and multiple sexual partnerships without a condom are high, this knowledge is not well utilized among youths, due to limited control over media content in the community.

Regarding community education, there was a strong relationship between community education and adolescent risky sexual behaviour. In Ghana and South Africa, community education increased the likelihood of engaging in risky sexual behaviour, which is consistent with a study conducted in Ghana and Kenya [42, 43], which found that community literacy level influences adolescents to engage in risky sexual behaviour. This may be linked to the unique community's cultural and religious practices conflicting with the global goals and policies on adolescents' sexual behaviour. This finding exposed a gap in the transmission of knowledge in a disorganized neighbourhood with high

Page 18/25 
literate individuals. While this explanation remains open for further interrogation, one implication of the findings is the effects of globalization on the traditional method of learning (i.e., within the family) to a dependency on the conventional style of learning (formal education). Moreover, coming from a larger-than-average-sized household reduced the likelihood of engaging in risky sexual behaviour, according to the findings. This result was expected given the proportion of young adolescents living in a non-poor neighbourhood. As a result, parents' household status may act as a protective factor for young people engaging in risky sexual behaviour, such as multiple sexual behaviours [44, 14], as well as improve their self-esteem, self-confidence, and self-autonomy in sexual relationships [45].

Regarding the place of residence, the findings reveal an association with risky sexual behaviours in all the countries surveyed. For example, urban neighbourhoods have a higher prevalence of adolescents engaging in risky sexual behaviour. Despite government and nongovernmental groups' efforts to raise awareness about risky sexual activity, this study indicated that neighbourhood characteristics contribute to a high prevalence of risky sexual conduct among adolescents. As a result, this research backs up earlier findings that preventive and "sensitization to risky sex" programs do not ensure a change in behaviour patterns $[46,47,48]$. Future research should investigate how limited media availability and poverty are linked to adolescent risky sexual behaviour in communities with a high number of literate parents since community media access and education were found to have a lower correlation with risky sexual behaviour among young people in the study.

\section{Limitation}

The current study was limited to never-married young individuals in Ghana, Rwanda, and South Africa, so there are some limits to this research. This restriction on never-married young individuals may have a high risk of bias/discordance when it comes to neighbourhood measures impacting early sexual debut and multiple sexual engagements. Despite these limitations, the findings are critical for more strategic policies and programs in preventing sexually transmitted infections, including HIV, and monitoring intervention programs to control the epidemic's spread, particularly among never-married young people in the three countries studied.

\section{Conclusion}

Following previous research, this study found a significant incidence of neighbourhood factors on risky sexual behaviour among adolescent males and females in all the countries analyzed, independent of their neighbourhood. Further research combining qualitative investigations is highly recommended to gain a deeper knowledge of the neighbourhood's predictor elements of higher risk sexual behaviour among adolescent males and females in SSA. Policymakers should create programs that help young people grasp the seriousness of the risks connected with early sexual debut and multiple sexual partnerships to make better decisions about their sexual lives.

\section{Policy implications}

The findings of this study on the influence of neighbourhood determinants of risky sexual behaviour (early sexual debut and multiple sexual partnerships) have several policy implications for future HIV/AIDS prevention among never-married young people in Ghana, Rwanda and South Africa. The findings would inform and help policymakers to consider appropriate policy options to reduce the prevalence of high-risk sexual behaviour, especially at the community level in sub-Sahara Africa. Additionally, in line with (12) observation, understanding high-risk of early sexual debut and engaging in multiple sexual partnerships among young people becomes an essential step toward reducing the spread of the HIV/AIDS epidemic

\section{List Of Abbreviations}

AIDS - Acquired Immunodeficiency Virus

aOR - Adjusted Odds Ratio

BCC - Behavioural Change and Communication

DHS - Demographic and Health Survey

HIV - Human Immunodeficiency Virus

HTC - HIV Testing and Counselling

MSP - Multiple Sexual partnerships 
$\mathrm{NDoH}$ - National Department of Health

OR - Unadjusted Odds Ratio

RC - Reference category

RSB - Risky Sexual Behaviour

SADHS - South African Demographic and Health Survey

SAMRC - South African Medical Research Council

SDT - Social Disorganisation Theory

Stats SA - Statistics South Africa

STIs - Sexually Transmitted Infections

VMC- Voluntary Male Circumcision

VPC - Variance Partition Coefficient

WHO - World Health Organization

\section{Declarations}

\section{Appreciations}

The authors are grateful to Ghana Statistical Service; National Institute of Statistics of Rwanda (NISR) [Rwanda], Ministry of Health (MOH) [Rwanda]; Statistics South Africa (Stats SA), South African Medical Research Council (SAMRC) and National Department of Health (NDoH) for making South Africa Demographic and Health Survey (SADHS) datasets publicly available that made this study possible.

\section{Acknowledgements}

The authors of this paper acknowledge DHS for freely providing data to conduct this research

\section{Authors' contributions}

COO: Conceptualization of the study and revision for important intellectual inputs; NHU accessed and used the dataset, literature review, statistical analysis and interpretation, drafting the manuscript, revision for intellectual inputs. All authors read and approved the final manuscript.

\section{Funding}

There is no funding to be declared for this research. This is an independent research

\section{Availability of data and materials}

Ghana Demographic and Health Survey (2014); Rwanda Demographic and Health Survey (2015): South Africa Demographic and Health Survey (2016) datasets are freely available at https://www.dhsprogram.com/data/dataset

\section{Ethics approval and consent to participate}

The data used for the analysis was obtained from a secondary datasets from Ghana, Rwanda and South Africa, with all identifier information removed. The survey was approved by the Ethics Committee of the Micro at Calverton in the USA and by the National Ethics Committee of each of the countries surveyed. All study participants gave informed consent before participation and all information was collected confidentially. The datasets were downloaded from the DHS website and the data is publicly available and unrestricted re-use for further analysis by researchers is permitted via open-license. Requisite permission in accessing and usage of dataset was obtained from the MEASURE-DHS archive. All methods used in this study are in compliance with the Ghana Statistics Service (GSS), National Institute of Statistics of Rwanda (NISR), and Statistics South Africa (Stats SA) guidelines 


\section{Consent for publication}

Not applicable

\section{Competing interests}

The authors declare that they have no competing interests.

\section{References}

1. Corder, K; Winpenny, E; Love, R; Brown, H. E; White, M \& Sluijs, E (2019). Change in physical activity from adolescence to early adulthood: a systematic review and meta-analysis of longitudinal cohort studies. British Association of Sport and Excercise Medicine, 53 (8); 496-503, https:/doi.org/10.1136/bjsports2016.097330

2. Currin, J. M; Molly E. I; Kassidy C \& Brittney L. G (2020). Sexually aroused: A mixed-methods analysis of how it feels for romantic and sexual partners to send and receive sext messages, Computers in Human Behavior, Volume 113, 2020, 106519, ISSN 0747-5632, https://doi.org/10.1016/j.chb.2020.106519.

3. Yaya, S \& Biswajit, G. (2018). Age at first sexual intercourse and multiple sexual partnerships among women in Nigeria: a crosssectional analysis. Frontiers in Medicine, 5(2018)171 00171, https//doi.org/10.3389/fmed.2018.00171

4. Ortiz-Echevarria L, Greeley M, Bawoke T, Zimmerman L, Robinson C \& Schlecht J. (2017). Understanding the unique experiences, perspectives and sexual and reproductive health needs of very young adolescents: Somali refugees in Ethiopia. Confl Health 11, 26 (2017). https://doi.org/10.1186/s13031-017-0129-6

5. Dick B. and Ferguson B.J. (2015).Health for the world's adolescents: A second chance in the second decade. J Adolesc Health. 2015; 56: 3-6

6. Dine, R.D., Bamodu, O.A. \& Ntaganira, J. 2021). Youth health risk behaviour: effects of early sexual debut on HIV incidence among Rwandan youth. J Public Health (Berl.) (2021). https://doi.org/10.1007/s10389-021-016178

7. Susan M. Igras, Marjorie Macieira, Elaine Murphy \& Rebecka Lundgren (2014) Investing in very young adolescents' sexual and reproductive health, Global Public Health, 9:5, 555-569, DOI: 10.1080/17441692.2014.908230

8. Biney, E; Ewemooje, O. S \& Amoateng, A. Y (2020): Predictors of sexual risk behaviour among unmarried persons aged 15-34 years in South Africa, The Social Science Journal, DOI: 10.1080/03623319.2020.1727225

9. Yang, L; Li, L; lona Y. Millwood, Sanne A.E. Peters, Yiping Chen, Yu Guo, Zheng Bian, Xiaofang Chen, Lingli Chen, Shixian Feng, Silu Lv, Zhigang Pang, Mark Woodward, \& Chen, Z (2017). Age at menarche and risk of major cardiovascular diseases: Evidence of birth cohort effects from a prospective study of 300,000 Chinese women, International Journal of Cardiology, 227 (2017) 497-502, https://doi.org/10.1016/j.ijcard.2016.10.115.

10. Said-Mohamed, R; Prioreschi, A; L. H; Heerden, N. A; Munthali, R. J; Kahn, K; Tollman, S. M; Houle,F. X. B; Dunger, D. B \& Norris, S. A (2018) Rural-urban variations in age at menarche, adult height, leg-length and abdominal adiposity in black South African women in transitioning South Africa, Annals of Human Biology, 45:2, 123-132, DOI: 10.1080/03014460.2018.1442497

11. Skoog T, Bayram Özdemir S. (2016). Explaining Why Early-Maturing Girls Are More Exposed to Sexual Harassment in Early Adolescence. The Journal of Early Adolescence. 2016;36(4):490-509. doi:10.1177/0272431614568198

12. Ibitoye M, Choi C, Tai H, Lee G, \& Sommer M. (2017) Early menarche: A systematic review of its effect on sexual and reproductive health in low- and middle-income countries. PLOS ONE 12(6): e0178884. https://doi.org/10.1371/journal.pone.0178884

13. Olufunmilayo I. Fawole, Omowumi O. Okedare, Mobolaji M. Salawu, Susan M. Kiene, \& Elizabeth Reed, (2021). Relationship dynamics with male partners among girls in low-income communities of Ibadan, Nigeria: Risk for violence and health-related consequences, Journal of Adolescence, 87(2021) 74-85, https://doi.org/10.1016/j.adolescence.2021.01.002.

14. Ajayi, A. I., \& Okeke, S. R. (2019). Protective sexual behaviours among young adults in Nigeria: Influence of family support and living with both parents. BMC Public Health, 19(983), 1-8. https://doi.org/10.1186/s12889-019-7310-3.

15. Odimegwu, C. O; De Wet, N \& Banda, P. C (2016). Risky sexual behaviour among women: does economic empowerment matter? Case of Gabon, Mozambique, Sierra-Leone and Zambia. African Journal of AIDS Research, 15(4): 333-340

16. Smith, L., Jacob, L., López-Sánchez, G. F., Grabovac, l., Yang, L., Pizzol, D., Sigman, A., McDermott, D., \& Koyanagi, A. (2020). A Multicountry Study of the Violence-Related Risk Factors for Early Sexual Debut and Risky Sexual Behavior in Adolescents. Journal of Interpersonal Violence. https://doi.org/10.1177/0886260520927502

17. Okano, J. T. \& Blower, S. Sex-specific maps of HIV epidemics in sub-Saharan Africa. Lancet Infect. Dis. 16, 1320-1322 (2016). 
18. Dwyer-Lindgren, L., Cork, M.A., Sligar, A. Krista M. Steuben1, Kate F. Wilson1 et al. (2019). Mapping HIV prevalence in sub-Saharan Africa between 2000 and 2017. Nature 570, 189-193 (2019). https://doi.org/10.1038/s41586-019-1200-9

19. Sun C (2018) HIV infection on the rise among Chinese college students. HIV/AIDS Res Treat Open J 5(1):e3-e4. https://doi.org/10.17140/HARTOJ-5-e012

20. Kathleen Ridgeway, Rachel Lenzi, Catherine Packer, Lázaro González-Calvo, Troy D. Moon, Ann F. Green \& Holly McClain Burke (2021) ‘l married when I was 16... due to poverty, I had no other way': multi-level factors influencing HIV-related sexual risk behaviours among adolescent girls in Zambézia, Mozambique, Culture, Health \& Sexuality, 23:3, 414-430, DOI: 10.1080/13691058.2020.1715483

21. Ministry of Health (MOH) (2019) Rwanda population-based HIV impact assessment 2018-2019, pp 2-7. https://phia.icap.columbia.edu/wp-content/uploads/2019/10/RPHIA-Summary Sheet_Oct-2019.pdf

22. Ministry of Health (MOH) [Rwanda] (2018a) National HIV/AIDS targets. http://www.rbc.gov.rw/IMG/pdf/rwanda_hiv_aids_2020_and_2030_targets.pdf

23. National Institute of Statistics of Rwanda (NISR) [Rwanda], Ministry of Health (MOH) [Rwanda], and ICF International (2015) Rwanda demographic health survey. NISR, MOH, and ICF International, Rockville, MD. https://dhsprogram.com/pubs/pdf/FR316/FR316.pdf

24. Asante, O. K; Nketiah-Amponsah, E; Andoh-Arthur, J; Boafo, I. M \& Ampaw, S (2018). Correlates of early sexual debut among sexually active youth in Ghana. International Quarterly of Community Health Education, 9(17): 39 https://doi.org/10.1177/0272684X18811016

25. WHO HIV guidelines (2021). Updated recommendations on HIV prevention, infant diagnosis, antiretroviral initiation and monitoring [Internet]. Geneva: World Health Organization

26. Marshall, E. J (2014). Adolescent Alcohol Use: Risks and Consequences, Alcohol and Alcoholism, Volume 49, Issue 2, March/April 2014, Pages 160-164, https://doi.org/10.1093/alcalc/agt180

27. Halonen JI, Kivimäki M, Pentti J, Kawachi I, Virtanen M, Martikanen, P; Subramanian, S. V \& Vahtera, J (2012). Quantifying Neighbourhood Socioeconomic Effects in Clustering of Behaviour-Related Risk Factors: A Multilevel Analysis. PLOS ONE 7(3): e32937. https://doi.org/10.1371/journal.pone.0032937

28. Madise N, Zulu E \& Ciera J. (2007). Is poverty a driver for risky sexual behaviour? Evidence from national surveys of adolescents in four African countries. African Journal of Reproductive Health 2007; 11:83-98.

29. Marshall, E. J (2014). Adolescent Alcohol Use: Risks and Consequences, Alcohol and Alcoholism, Volume 49, Issue 2, March/April 2014, Pages 160-164, https://doi.org/10.1093/alcalc/agt180

30. Uchudi, J., Magadi, M., \& Mostazir, M. (2012). A multilevel analysis of the determinants of high-risk sexual behaviour in sub-Saharan Africa. Journal of Biosocial Sciences, 44(3):289- 311.

31. Brodish, P. (2015). An association between neighbourhood wealth inequality and HIV prevalence in sun-Saharan Africa. Journal of Biosocial Science, 47(3), 311-328, https//www.doi:10:1017/S0021932013000709

32. Ganle, J.K., Amoako, D., Baatiema, L \& Ibrahim, M (2019). Risky sexual behaviour and contraceptive use in contexts of displacement: insights from a cross-sectional survey of female adolescent refugees in Ghana. International Journal of Equity Health 18, 127 (2019). https://doi.org/10.1186/s12939-019-1031-1

33. Liu, G., Hariri, S., Bradley, H., Gottlieb, S. L., Leichliter, J. S., \& Markowitz, L. E. (2015). Trends and patterns of sexual behaviours among adolescents and adults aged 14 to 59 years, United States. Sexually Transmitted Diseases42 (1), 20-26.

34. Hewitt, A. N; Beauregard, E; Andresen, M. A \& Brantingham. P. L (2018). identifying the nature of risky places for a sexual crime: The applicability of crime pattern and social disorganization theories in a Canadian context. Journal of Criminal Justice, 57, 35-46, https://doi.org/10.1016/j.jcrimjus.2018.03.003,

35. Nwalozie, C. J. (2015). Rethinking subculture and subcultural theory in the study of youth crime: A theoretical discourse. Journal of Theoretical \& Philosophical Criminology, 7(1), 1-16.

36. Rustein, S. O., \& Kiersten, J. (2004). The DHS wealth index. Calverton, Maryland: ORC Macro, DHS comparative reports No. 6; 2004.

37. Musiime, K. E \& Mugisha, J. F (2015). Factors Associated with Sexual Behaviour among Students of Uganda Martyrs University. International Journal of Public Health Research. Vol. 3, No. 1, 2015, pp. 85-93.

38. Cleopatra, K \& Kusanthan, T (2017). Gender differential sexual risk-taking behaviour and substance abuse among out of school adolescents in Lusaka. International Journal of Humanities and Social Studies, Iv(ii): 103-120

39. Brown D. W, Riley L, Butchart A, Meddings DR, Kann L, Harvey AP. (2009). Exposure to physical and sexual violence and adverse health behaviours in African children: results from the Global School-based Student Health Survey. Bull World Health Organ. 87(6):447-55.

40. Lalor K, \& McElvaney R. (2010). Child sexual abuse links to later sexual exploitation/high-risk sexual behaviour, and prevention/treatment programs. Trauma Violence Abuse. 11(4):159-77

Page 22/25 
41. Booysen, F., \& Summerton, J. (2002). Poverty, Risky Sexual Behaviour, and Vulnerability to HIV Infection: Evidence from South Africa. Health, Population and Nutrition, 20(4), 285-288.

42. Kim, J; Rik, C; Bart, V. B; Ronel, R \& Reddy, P. (2016).Teenage pregnancy rates and associations with other health risk behaviours: a three-wave cross-sectional study among South African school-going adolescents, Reproductive Health, 50(13)1, https://doi.org/10.1186/s12978-016-0170-8

43. Asmamaw, M. A; Mullu, K. G; Kidanemariam, B. A \& Abeje, F. G (2017). Prevalence and determinants of risky sexual practice in Ethiopia: Systematic review and Meta-analysis, Reproductive Health, 113(14):1742-4755,

44. Darteh, E.K.M., Dickson, K.S. \& Amu, H. Understanding the Socio-demographic Factors Surrounding Young Peoples' Risky Sexual Behaviour in Ghana and Kenya. J Community Health 45, 141-147 (2020). https://doi.org/10.1007/s10900-019-00726-6

45. Ssewanyana D, Abubakar A, Newton CRJC, Otiende M, Mochamah G, Nyundo C, Walumbe, D; Nyutu, G; Amadi, D; Doyle, A. M; Ross, D. A; Nyagura, A; Williams, T.N \& Bauni, E. (2020) Clustering of health risk behaviours among adolescents in Kilifi, Kenya, a rural SubSaharan African setting. PLoS ONE 15(11): e0242186. https://doi.org/10.1371/journal.pone.0242186

46. Govender, K., Cowden, R. G., Asante, K. O., George, G., \& Reardon, C. (2019). Sexual risk behaviour: a multi-system model of risk and protective factors in South African adolescents. Prevention Science, 20(7), 1054-1065. https://doi.org/10.1007/s11121-019-01015-3.

47. Biyase, M., \& Zwane, T. (2018). An Empirical Analysis of the Determinants of Poverty and Household Welfare in South Africa. The Journal of Developing Areas 52(1), 115-130. doi:10.1353/jda.2018.0008.

48. Regmi, P., Simkhada, P., \& Van Teijlingen, E. R. (2008). Sexual and reproductive health status among young peoples in Nepal: Opportunities and barriers for sexual health education and services utilization. Kathmandu University Medical Journal, 6(2), $248-256$. http://www.ncbi.nlm.nih.gov/pubmed/18769100.

49. Doyle, A. M., Ross, D., Maganja, K., Baisley, K., Masesa, C., Andreasen, A., \& Hayes, R. J. (2010). Long-term biological and behavioural impact of an adolescent sexual health intervention in Tanzania: Follow-up survey of the community-based mema kwa vijana trial. PLoS Medicine, 7(6), e1000287. http://dx.doi.org/10.1371/journal.pmed.1000287

50. Odimegwu, C., \& Somefun, O.D.(2017). Ethnicity, gender and risky sexual behaviour among Nigerian youth: an alternative explanation. Reprod Health 14, 16 (2017). https://doi.org/10.1186/s12978-017-0284-7

51. Okano, J. T. \& Blower, S. (2016). Sex-specific maps of HIV epidemics in sub-Saharan Africa. Lancet Infect. Dis. 16, 1320-1322 (2016).

\section{Figures}




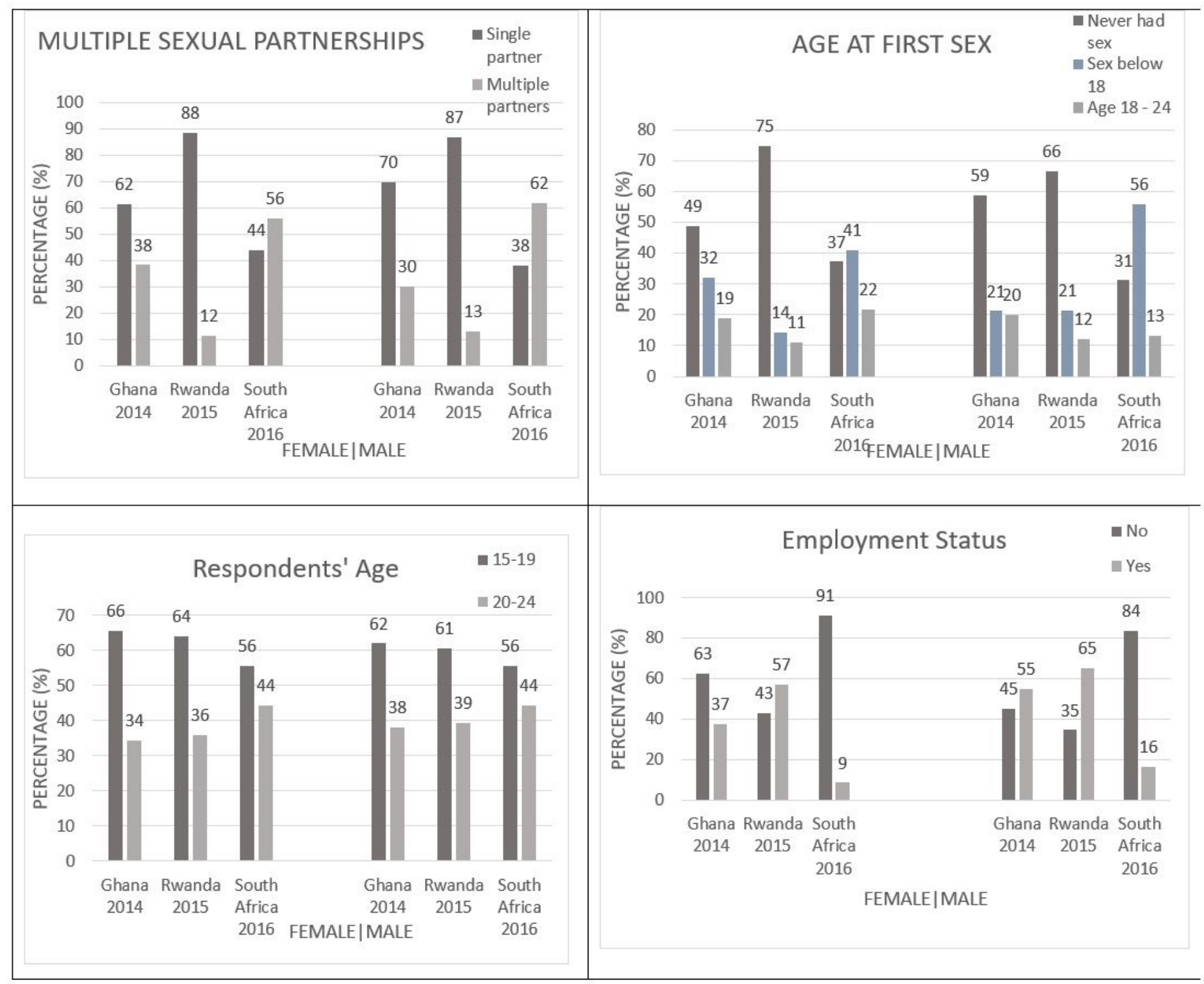

Figure 1

prevalence of adolescent risky sexual behaviour by MSP, Age at FS sex, Respondents' age and Employment status. Source: (DHS) Ghana 2014; Rwanda 2015 and South Africa 2016 


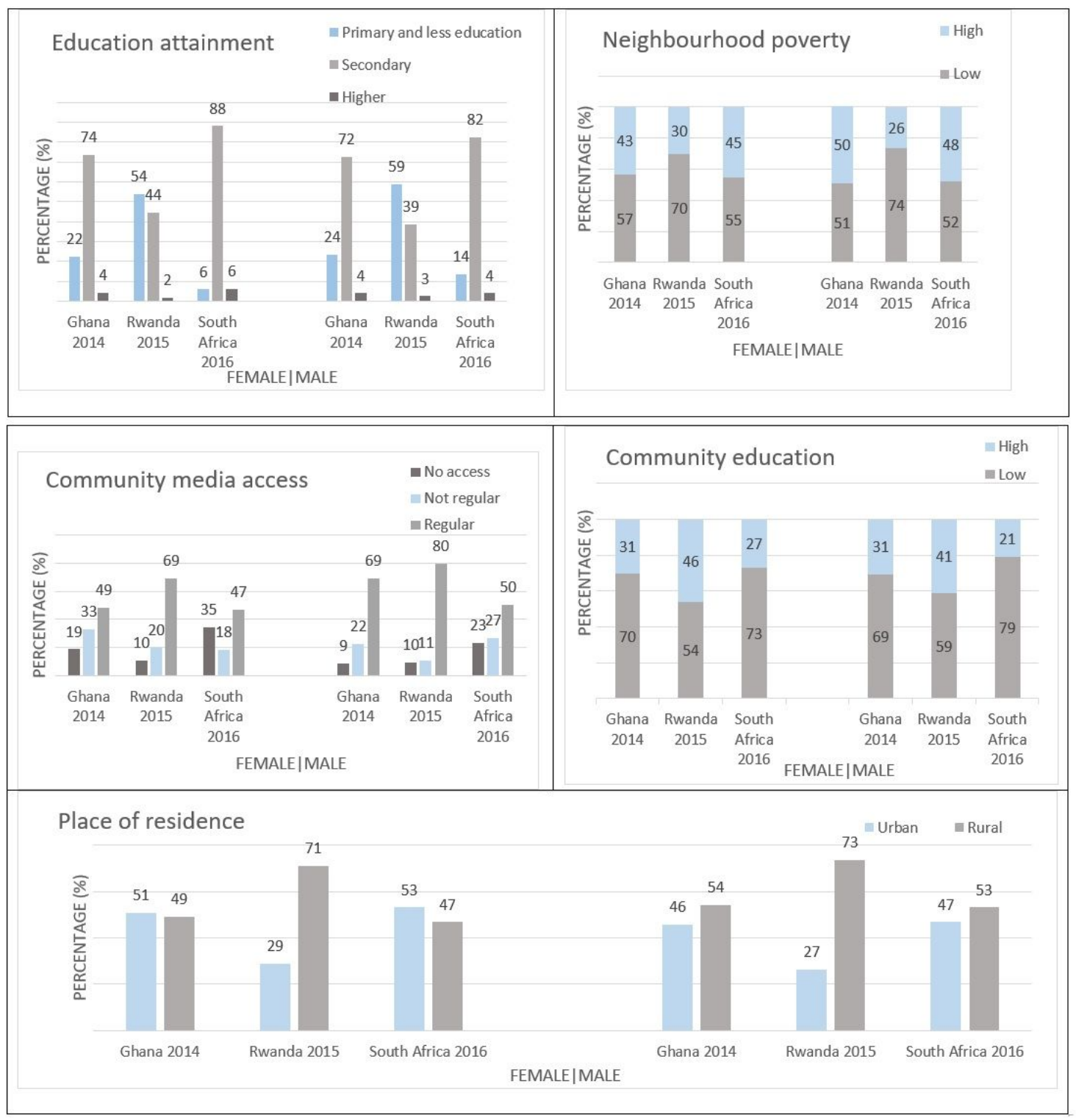

\section{Figure 2}

prevalence of risky sexual behaviour by education, neighbourhood poverty, community education, community media access and place of residence. Source: (DHS) Ghana 2014; Rwanda 2015 and South Africa 2016 